\title{
Geotechnical Investigation and Effect of Moisture Content on Subgrade CBR Values; Arbaminch-Chencha Existing Road; Ethiopia
}

\author{
Defaru Katise Dasho \\ Department of Civil Engineering in Arba Minch University \\ Arba MInch, Ethiopia
}

\begin{abstract}
In the flexible pavements sub-grade is the undermost layer for pavement structure constructed on it and used to resist traffic load. Hence, subgrade geotechnical behaviors are considered as measuring parameters of the pavement design and performance. But, here Arbaminch-Chencha road is constructed as gravel road twelve years so far without any geotechnical investigation.

The aim of this research is geotechnical investigation and effect of moisture content on CBR of the subgrade soil of ArbaminchChencha road. This is to classify and characterize this subgrade according to its geotechnical properties, to identify effect of moisture on subgrade CBR for selected three soil classes.

To achieve these objectives, seventeen representative test samples collected along the existing road. Laboratory investigations performed for in-situ moisture content, specific gravity, grain size analysis, Atterberg's limit test for all pit samples. And then soils are classified. After classification of soils; laboratory moisture - density relationship and CBR values are determined. The effect of moisture on its CBR was observed for specified soil classes. For all tests the apparatus and the procedures used for analysis were done according to ASTM and AASHTO standards.
\end{abstract}

According to AASHTO soil classification, Arbaminch-Chencha road subgrade soils classified as coarse and fine grained soil; but dominated by fine grained soil class.

As per observed, laboratory maximum dry density of this soil ranges from $1.36 \mathrm{gm}$./cc to $2.11 \mathrm{gm}$./cc and OMC range from 10 $\%$ to $30 \%$. And four day soaked CBR Values are ranges from 3 $\%$ to $49 \%$ under specification of $95 \%$ MDD.

Effect of moisture revealed as, CBR value reduced $4 \%$ to $28 \%$ at dry side whereas $25 \%$ to $59 \%$ at wet side of OMC and MDD of specified soil classes.

Saturation after 48 to 96 hours, CBR reduced from $17 \%$ to $30 \%$ whereas 96 to 144 hours reduced $7 \%$ to $20 \%$. But, continuous and linear reduction observed in finer soil classes.

Key words: Sub Grade, classification, Characterization, Moisture Content and CBR.

\section{INTRODUCTION}

In the highway pavement structure, sub-grade is a naturally consolidated and/or constructed layer to resist traffic load which provides a suitable foundation for the pavement layer constructed on it. Hence, sufficient information on soil class, characteristics and mechanical properties (basically California Bearing Ratio) of foundation material is very important for engineering constructions; such as road projects.

Arbaminch-Chencha road is found in Gamo Gofa Zone, in southern Ethiopia; which is constructed twelve years before (in 2005). This road is currently gravel paved with having

\author{
Prof. R. Kumer Verma \\ Department of Civil Engineering in Arba Minch University \\ Arba MInch, Ethiopia
}

heavy traffic flow. Hence, it gives large transportation purpose for different areas around and far from the road. Areas using this road are to and from Arbaminch-Dorze, Chencha, Ezo, Ditta, Dara Malo (Waca), Abassa, and to other currently developing small towns and villages. This encourages the social and economic development activities of these areas by transporting an industrial raw products (textiles) and wide agricultural products (fruits; Apple, Apple mango etc.), potato, maize, animals for meat) of the Arbaminch-Chencha highlands.

Although, with having heavy traffic flow and transportation purpose by small vehicles to heavy trucks, it is till now a low class gravel road constructed so far without any geotechnical investigation on its subgrade soil. As information collected from Gamo-Gofa road and transport office, ArbaminchChencha road is constructed under this office as a client and they informed for this research work as no soil investigation conducted during that time at all.

But now a day this road is under investigation by ERA for upgrading it to asphalt concrete level because of its heavy transportation purpose and the rapid development of community there. Since, every activity requires quality road as much as possible to transport different products as discussed in above paragraph.

Hence, the present research is directed on geotechnical investigation and effect of moisture content on CBR values on subgrade soil of Arbaminch-Chencha existing road.

\section{STATEMENT OF THE PROBLEM}

Investigation of soil and soil materials is so important since all infrastructure construction projects (like roads) use naturally occurring soils and soil Martials as the basic foundation as well as construction materials. Unlike manmade materials, the properties of these soil are highly variable and a function of the complex natural processes that occurred in the geologic past. And are heterogeneous, nonlinear material, and typically anisotropic instead of being isotropic. As a consequence, constructions like pavement structures are facing problems related with soils and soil materials available in the project site, whose properties are often unknown and of variable quality.

Arbaminch-Chencha road was constructed without any geotechnical investigation and has been giving transportation purpose for the community with continuous maintenance twice per year on most part of the road. These maintenances are conducting just before and after rainy season. This is 
because of the capacity of this road is not equivalent to its purpose; since it was gravel paved.

Most of this road section is found in different climate zones according to Ethiopian climate zoning. Particularly, there is high precipitation and low temperature is common at the end section of the study area; Dorze - Chencha section. Rain water stays for more than a week in poorly constructed side ditch during rainy seasons in this section. Not only climate problem, but also there is shallow ground water table near to the surface about 2 to $3 \mathrm{~m}$. This ground water "(BONO)" is used for day to day purpose of the area. Due to this, subgrade strength (CBR value) can be affected by long term moisture saturation. But when the road comes to the starting point of this research, climate is different from the above section; in which precipitation is low with high temperature.

The subgrade strength owing to its inconsistency or variable nature poses a challenge to come up with a perfect design of pavement on it. Since, the subgrade is always subjected to change in its moisture content due to precipitation, capillary action, flood or abrupt rise of water table. Change in moisture content causes change in the subgrade strength. And it becomes quite essential for an engineer to understand the exact nature of dependence of subgrade strength on moisture content.

Therefore, this research is helpful to know the geotechnical behavior and effect of moisture content on CBR values of the subgrade soil was studied.

\section{OBJECTIVE OF THE STUDY}

\subsection{General Objective}

The general objective of this research is geotechnical investigation for subgrade and effect of moisture content on its subgrade CBR values of Arbaminch-Chencha existing road.

\subsection{Specific Objectives}

The specific objectives of this research work are:
* To classify and characterize subgrade soils found along Arbaminch-Chencha road alignment; for road construction purpose. By using in-situ moisture content, specific gravity, grain size analysis test and atterberg's limt tests

* To determine laboratory compaction characteristics and subgrade CBR values of subgrade in the Arbaminch-Chencha road and

* To experiment and evaluate the effect of moisture content on subgrade CBR in this road alignment

\section{METHODOLOGY}

To achieve the objectives, seventeen (17) sampling pits areas selected and their geographical location is determined in field using GPS reading. From these sample pits, disturbed subgrade soil samples were excavated to a maximum depth of 1.5 meters and collected for laboratory investigation (as per ERA site investigation manual 2013).

Laboratory tests were conducted for natural moisture content, specific gravity, Atterberg's limit test, grain size analysis on all seventeen samples. And moisture-density relationship, CBR and CBR swelling under OMC is performed on ten specified pit samples.

Lastly, the effect of moisture content on CBR values is evaluated for different soil classes by (1) by varying moisture content during preparation of CBR specimens before (dry side) and after (wet side) OMC; (2) by extending saturation period beyond 96hours (4days) to 144hours (6days). During any activity for this research, special attentions paid for the sack of tropical residual soil properties; even though there is no given standard to investigate such type of soils.

For 17 pit samples of subgrade soil along road stretch, pit chainage was started from Chano (pit -1 ; stationed $9+160$ by considering 0+000 station at Arbaminch town) and proceeded to Chencha town (pit -17 ; stationed $27+200$ ) as shown in figure 4.1. Chano town exists $9 \mathrm{~km}$ from Arbaminch to east on the Addis Ababa Arbaminch main highway.

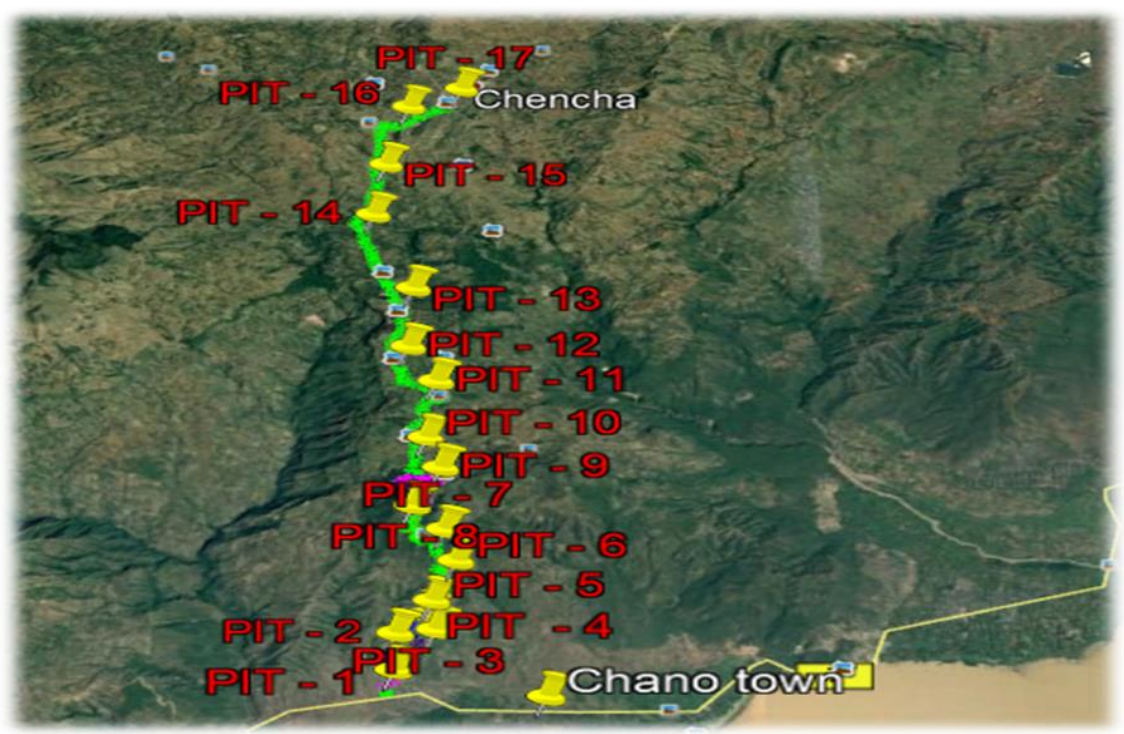

Figure 4.1; Arbaminch - Chencha - Chano Road Profile (Google earth.com) 
Location of pits taken some distance offset right hand side(RHS) or left hand side(LHS) from centerline of road, since road is under use. So that is impossible to dig pits just at centerline of road which was justified in the following table 4.1.

Table 4.1 Summary of Pit Location for each sample

\begin{tabular}{|c|c|c|c|c|}
\hline \multirow[b]{2}{*}{ pit } & \multirow{2}{*}{$\begin{array}{l}\text { Chainage } \\
\text { (Station) }\end{array}$} & \multicolumn{3}{|c|}{ Location Coordinate } \\
\hline & & $\begin{array}{l}\text { Latitude } \\
(\mathrm{N})\end{array}$ & $\begin{array}{l}\text { Longitude ( } \\
\text { E) }\end{array}$ & $\begin{array}{c}\text { Altitude }(\mathrm{m}) \\
\text { from msl }\end{array}$ \\
\hline 1 & $9+160$ & 6'07'10.49'" & 37'34'32.01'" & 1262.3 \\
\hline 2 & $10+200$ & 6'07'34.24'" & 37'34'31.67'" & 1343.86 \\
\hline 3 & $11+100$ & 6'07'35.10'' & 37'34'42.12'" & 1404.88 \\
\hline 4 & $12+000$ & 6'7'47.01'" & 37'34'44.35" & 1451.5 \\
\hline 5 & $13+060$ & '6'07'56.35' & 37'34'47.43' & 1502 \\
\hline 6 & $14+320$ & 6'08'23.95'" & 37'34'55.85'” & 1612.23 \\
\hline 7 & $15+380$ & 6'8'46.02'" & 37'34'49.88" & 1732.788 \\
\hline 8 & $16+500$ & 6'09"3.27" & 37'34'36.37' & 1818.41 \\
\hline 9 & $17+660$ & 6'9'29.10' & 37'34'46.41" & 1958.0352 \\
\hline 10 & $19+900$ & 6'9'49.70' & 37'34'39.24" & 2132.1 \\
\hline 11 & $21+000$ & 6'10'32.41'" & 37'34'41.51'" & 2220.46 \\
\hline 12 & $22+040$ & 6'10'58.54"' & 37'34'27.53'" & 2377.41 \\
\hline 13 & $23+300$ & 6'11'46.05" & 37'34'27.02" & 2462.78 \\
\hline 14 & $24+220$ & 6'12'36" & $37^{\prime} 34^{\prime} 6.50^{\prime \prime}$ & 2559.68 \\
\hline 15 & $25+400$ & 6'13'33.36" & 37'34'6.93”' & 2559.41 \\
\hline 16 & $26+420$ & "6'14'13.77' & 37'34'5.33' & 2604.34 \\
\hline 17 & $27+200$ & 6'14'41.66'" & 37'34'39.6"' & 2690.75 \\
\hline
\end{tabular}

\subsection{GEOTECHNICAL INVESTIGATION}

Geotechnical investigations to be conducted are summarized in the following table 4.2

Table 4.2 Summary of tests conducted, standards, and their significance

\begin{tabular}{|c|c|c|c|c|}
\hline S.No & Tests conducted & Test method/standard & Pits investigated & Selection \\
\hline 1 & In-situ moisture content (w) & AASHTO T 265 or ASTM D 2216 & All 17 pits & All 17 pits \\
\hline 2 & Specific Gravity(Gs) & AASHTO T100 or ASTM D854 & All 17 pits & All 17 pits \\
\hline 3 & Liquid limit(LL) & AASHTO T89 / ASTM D 4318 & All 17 pits & All 17 pits \\
\hline 4 & Plastic Limit (PL) & AASHTO T90/ ASTM D 4318 & All 17 pits & All 17 pits \\
\hline 5 & Sieve analysis & AASHTO T 88 / ASTM D 422 & All 17 pits & All 17 pits \\
\hline 6 & $\begin{array}{l}\text { Moisture- Density Relations of } \\
\text { Soils }\end{array}$ & $\begin{array}{c}\text { AASHTO T180-97, / ASTM } \\
\text { D2937 }\end{array}$ & $\begin{array}{l}\text { For } 10 \text { from } 17 \\
\text { pits }\end{array}$ & $\begin{array}{c}\text { Pit } 1,2,3,5,6,8,11,12,14 \\
\text { and } 16\end{array}$ \\
\hline 7 & $\begin{array}{c}\text { CBR and swell at OMC and } \\
\text { MDD }\end{array}$ & AASHTO T-193 & $\begin{array}{l}\text { For } 10 \text { from } 17 \\
\text { pits }\end{array}$ & $\begin{array}{c}\text { Pit } 1,2,3,5,6,8,11,12,14 \\
\text { and } 16\end{array}$ \\
\hline 8 & $\begin{array}{l}\text { Effect of moisture content on } \\
\text { CBR }\end{array}$ & AASHTO T-193 & For 3 from 17 pits & Pit 1,5 , and 14 \\
\hline
\end{tabular}

Selection of pits for various tests was made on the following criteria: (1) variability of subgrade soil along the roadway, (2) consideration on samples taken from these variable locations are representative for overall subgrade along this road. And also (3) distance of minimum of 2 to $3 \mathrm{~km}$ distance between these pits as much as possible as per ERA pavement design manual; vloume1, 2013. Manual recommends taking strength test samples with limit of 2 to $5 \mathrm{~km}$ to have economical design. Since, it is too costly to design subgrade CBR with in shorter distance less than $2 \mathrm{~km}$.

\subsection{Effect of Moisture Content on CBR Values of Subgrade}

The variation of moisture in soils has great adverse impact on quality and performance of structures constructed on it. Since, increase in moisture content in substructure material decreases the engineering quality of soil; like load bearing capacity. The variation of moisture content in soil and soil materials may be developed most likely from climate change as discussed in chapter two.

Thus, Arbamich-chencha road has two different climate zones; these are (1) road near Arbaminch (about $9 \mathrm{~km}$ from $19 \mathrm{~km}$ total road) which has more hot time and more evaporation than precipitation per year and (2) the second part is road near Chencha (about $10 \mathrm{~km}$ from $19 \mathrm{~km}$ total road) part in which there is more precipitation and low temperature, shallow ground water table ( $2 \mathrm{~m}$ to $3 \mathrm{~m})$. Hence, moisture fluctuation and its effect on subgrade bearing capacity were expected, particularly during rainy seasons.

This research work was conducted to study moisture effect on subgrade CBR value in two ways: (1) Preparing CBR specimens with water contents at dry side and wet side of $\mathrm{OMC}$ and (2) preparing CBR specimens at OMC but varying the degree of saturation (period of saturation). 
Three soil classes (pit-1; A-2-4 soil class, pit-5; A-7-5 soil class and pit-14; A-4 soil class) were selected for the above tests. These selections were made on the bases of soil classification, CBR values and to cover over all study area along the road.

\subsubsection{Effect of Moisture Content on CBR Values by drying} and wetting

Materials used in this section were the same as used in normal (conventional CBR test) CBR test in section 4.1. Air dried soil materials passing $19 \mathrm{~mm}$ prepared and modified if material has larger size than $19 \mathrm{~mm}$.

The variable parameter selected in this case was moisture content. Two moisture contents were selected on dry side of OMC and two on wet side as discussed in chapter five and other parameters were kept constant as much as possible.

So that, four CBR specimens were prepared; two CBR specimens at dry side and two on wet side. Each CBR specimen from these soil classes was compacted by energy of 56 blows per layer to make variables other than moisture content constant. Dry density and moisture contents were determined. Then after, these remolded CBR specimens were soaked for 96 hours with surcharge load of $4.56 \mathrm{~kg}$. Initial and final readings for percentage of swelling were taken before and after soaked for determination of swelling.

\subsubsection{Effect of Moisture on CBR values by Period of Saturation}

The second way performed here to evaluate effect of moisture content on CBR values of subgrade was extended saturation period. Commonly, it is popular to use 96 hour's soaked CBR values of subgrade for the design of pavement structures. This was accepted by considering 96 hours saturated is the worst and CBR value at this period is the lowest and no effect could be observed.

However, this condition may difficult to accept in some conditions such as at area in which there is high rainfall and low temperature soaking CBR specimens for 96 hours can't saturate fully whereas at areas in which there is low rainfall and high temperature soaking CBR specimens for 96 hours not logical. Since, in the first case moisture can affect CBR values by gradual saturation for longer time than 96 hours. And for the second case 96 hours soaked CBR values are not economical because of no such effect could be expected.

Thus, for this research the effect of moisture content was studied by varying saturation period 0,2 (48 hours), 4(96 hours) and 6(144 hours) days on CBR specimens from those selected soil samples.

To do so, four CBR specimens from above three soil classes were prepared by OMC and compacted in 56 blows per layer. Materials used here were the same material as materials used in section 4.2.1. These specimens (unsoaked, 2 days soaked, 4 days soaked and 6 days soaked) were soaked for corresponding saturation periods under surcharge load of $4.56 \mathrm{~kg}$. Dry density, moisture content and percentage of swelling all were determined the same way as procedures taken in conventional CBR test AASTO T193.

But moisture content was taken from three points (top about 2 $\mathrm{cm}$ below from the top edge of the mold, middle and bottom about $2 \mathrm{~cm}$ above from the bottom edge of the mold) from single CBR specimen and determined as per ASTM D2216/AASHTO T265. Then the average of three is used for density determination of CBR specimen for each soil.

CBR values and percentage of swelling for every unsoaked, soaked for 2, 4 and 6 days specimens were determined as described. And overall observed, analyzed, tables and figures are collected in section 5.2.

\section{RESULTS AND DISCUSSIONS}

\subsection{Geotechnical Investigation}

In this chapter, investigation results discussed are: in-situ moisture content, specific gravity, soil classification tests such as sieve analysis and Atterberg's limit (Liquid limit, Plastic limit, and Plasticity Index value) are presented. Soils are classified. Then laboratory moisture-density characteristics and $\mathrm{CBR}$ test under normal conditions (at OMC and MDD) were explained.

The effect of moisture content observed under moisture content other than OMC and extended degree of saturation period results are presented here. All the laboratory results are summarized in tables and figure in the following sections.

\subsubsection{In-Situ Moisture Content}

Methods of determination of in-situ moisture contents in samples collected from 17 pits are presented in section 4.1. The results obtained from these tests are presented in table 5.1. As their results indicated that there was variation of moisture content observed from pit to pit (table 5.1) along the road. The variation was most likely due to the location of pits with respect to their elevation and weather condition. This was not only the reason but also soil by itself varies from pit to pit along the road. In-situ moisture content was relatively higher at higher elevations near Chencha and the reverse was also true. Pit samples containing fine soil content had the greater in-situ moisture than those containing lesser fine soil or more coarser particles.

Soils here under study for this research, the in-situ moisture content obtained from laboratory undisturbed and disturbed samples by ASTM D2216/ASHTO T-265 range in between $10 \%$ to $44 \%$ except pit 16 has $73 \%$ ( which was relatively higher and close to its liquid limit). The average of all test results was $30.15 \%$ which is more likely in range of silty and clayey soil. Since, most part of soils in the study area was dominated by fine grained soil class.

\subsubsection{Specific Gravity}

Method to determine the specific gravity is described in section 4.1. From that, results of specific gravity at $20{ }^{\circ} \mathrm{c}$ of seventeen pit samples are tabulated in table 5.1. Specific gravity of soil solids may vary with varying the mineralogical content of the soil. 
Table 5.1: Laboratory in-situ moisture and specific gravity summary

\begin{tabular}{|c|c|c|c|c|c|}
\hline \multirow[t]{2}{*}{ Pits } & Chainage & \multirow{2}{*}{$\begin{array}{c}\text { Depth } \\
\text { sampled }(\mathrm{m})\end{array}$} & \multirow{2}{*}{$\begin{array}{l}\text { In situ moisture } \\
\text { content (w \%) }\end{array}$} & $\begin{array}{l}\text { Specific } \\
\text { Gravity }\end{array}$ & \multirow{2}{*}{$\begin{array}{c}\text { Elevation(m) } \\
\text { From M.s.l }\end{array}$} \\
\hline & (station) & & & $\mathrm{Gs}\left(\right.$ at $\left.20^{\circ} \mathrm{c}\right)$ & \\
\hline Pit - 1 & $9+160$ & 0.50 & 10.53 & 2.63 & 1262.30 \\
\hline Pit - 2 & $10+200$ & 0.75 & 11.41 & 2.67 & 1343.86 \\
\hline Pit - 3 & $11+100$ & 0.50 & 10.88 & 2.65 & 1404.88 \\
\hline Pit - 4 & $12+00$ & 0.50 & 14.97 & 2.62 & 1451.50 \\
\hline Pit - 5 & $13+060$ & 0.75 & 23.18 & 2.68 & 1502.00 \\
\hline Pit - 6 & $14+320$ & 1.20 & 41.17 & 2.75 & 1612.23 \\
\hline Pit - 7 & $15+380$ & 0.50 & 24.90 & 2.70 & 1732.79 \\
\hline Pit -8 & $16+500$ & 0.50 & 9.88 & 2.64 & 1818.41 \\
\hline Pit - 9 & $17+660$ & 0.50 & 31.95 & 2.69 & 1958.04 \\
\hline Pit - 10 & $19+900$ & 0.50 & 35.23 & 2.73 & 2132.10 \\
\hline Pit - 11 & $21+000$ & 0.50 & 42.00 & 2.62 & 2220.46 \\
\hline Pit - 12 & $22+040$ & 1.15 & 28.28 & 2.68 & 2377.41 \\
\hline Pit - 13 & $23+300$ & 0.75 & 31.26 & 2.72 & 2462.78 \\
\hline Pit - 14 & $24+220$ & 0.75 & 37.25 & 2.65 & 2559.68 \\
\hline Pit - 15 & $25+400$ & 0.75 & 43.58 & 2.66 & 2559.41 \\
\hline Pit - 16 & $26+420$ & 1.50 & 73.09 & 2.65 & 2604.34 \\
\hline Pit - 17 & $27+200$ & 0.75 & 42.99 & 2.67 & 2690.75 \\
\hline
\end{tabular}

The results of specific gravity vary from soil class to soil class. Hence, its values of the study area varies from 2.622.75 which is in the range of typical specific gravity values of gravel, sand, silt and clay soils. The lower values represent coarser soils and the higher values are for finer soils.

\subsubsection{Grain Size Analysis}

The grain size analysis test performed to have group of soil grains with in their corresponding sizes which are helpful for plasticity characteristics and soil classification. Here table 5.2 is developed as summary for seventeen pit samples from grain size observations and analyzed results.

The grain size analysis results indicate that the dominant proportion of particle in the study area is fine soil (silt and clay) of average percentage of $44.17 \%$ and the second dominancy by sand size of average of $39.07 \%$ and the last was gravel of average of $16.46 \%$. As observed in table above, soils are finer and finer when it approaching to higher elevation along the road. Therefore, finer soils are found around Chencha town.

Table 5.2: Summary of grain size analysis of all 17 pits

\begin{tabular}{||c|c|c|c|c|c|c|c||}
\hline \hline \multirow{2}{*}{ PITS } & \multirow{2}{*}{$\begin{array}{c}\text { Chainage(St } \\
\text { ations) }\end{array}$} & \multicolumn{2}{|c|}{ AASHTO T88; \% ge of pass } & \multicolumn{3}{c||}{ \% ge of soils } \\
\cline { 3 - 8 } & & $4.75 \mathrm{~mm}$ & $0.425 \mathrm{~mm}$ & $0.075 \mathrm{~mm}$ & $\begin{array}{c}\text { Gravel}(>4.75 \\
\mathrm{mm})\end{array}$ & $\begin{array}{c}\text { Sand(4.75 - } \\
0.075)\end{array}$ & $\begin{array}{c}\text { fine }(< \\
0.075 \mathrm{~mm})\end{array}$ \\
\hline 1 & $9+160$ & 59.79 & 31.18 & 25.30 & 40.26 & 34.44 & 25.30 \\
\hline 2 & $10+200$ & 81.04 & 44.85 & 31.28 & 18.96 & 49.76 & 31.28 \\
\hline 3 & $11+100$ & 47.22 & 16.72 & 14.36 & 52.78 & 32.86 & 14.36 \\
\hline 4 & $12+000$ & 81.65 & 35.82 & 17.59 & 18.35 & 64.07 & 17.59 \\
\hline 5 & $13+060$ & 96.69 & 80.81 & 62.89 & 3.31 & 33.8 & 62.89 \\
\hline 6 & $14+320$ & 99.52 & 91.83 & 73.23 & 0.48 & 26.29 & 73.23 \\
\hline 7 & $15+380$ & 73.06 & 46.27 & 26.37 & 26.94 & 46.69 & 26.37 \\
\hline 8 & $16+500$ & 43.81 & 12.15 & 4.66 & 56.19 & 39.15 & 4.66 \\
\hline 9 & $17+660$ & 92.55 & 64.23 & 46.45 & 7.46 & 46.1 & 45.45 \\
\hline 10 & $19+900$ & 94 & 68.19 & 51.96 & 6.00 & 42.04 & 51.96 \\
\hline 11 & $21+000$ & 64.04 & 21.72 & 16.62 & 35.96 & 47.42 & 16.62 \\
\hline 12 & $22+040$ & 99.36 & 82.29 & 63.83 & 0.64 & 35.53 & 63.83 \\
\hline 13 & $23+300$ & 93.5 & 63.11 & 53.09 & 6.50 & 40.41 & 53.09 \\
\hline 14 & $24+220$ & 96.37 & 79.18 & 65.39 & 3.63 & 30.98 & 65.39 \\
\hline 15 & $25+400$ & 99.3 & 74.01 & 54.1 & 0.71 & 45.2 & 54.1 \\
\hline 16 & $26+420$ & 98.59 & 91.04 & 76.96 & 1.41 & 21.63 & 76.96 \\
\hline 17 & $27+200$ & 99.77 & 86.28 & 71.96 & 0.23 & 27.81 & 71.96 \\
\hline
\end{tabular}


5.1.4 Atterberg Limits test results

As described in chapter four, results of Atterberg limits (liquid limit, plastic limit) are determined according to
AASHTO T-89 and T-90 standard test methods. Typical liquid limit test flow curve is given in Figure 5.1 for sample pit-1.

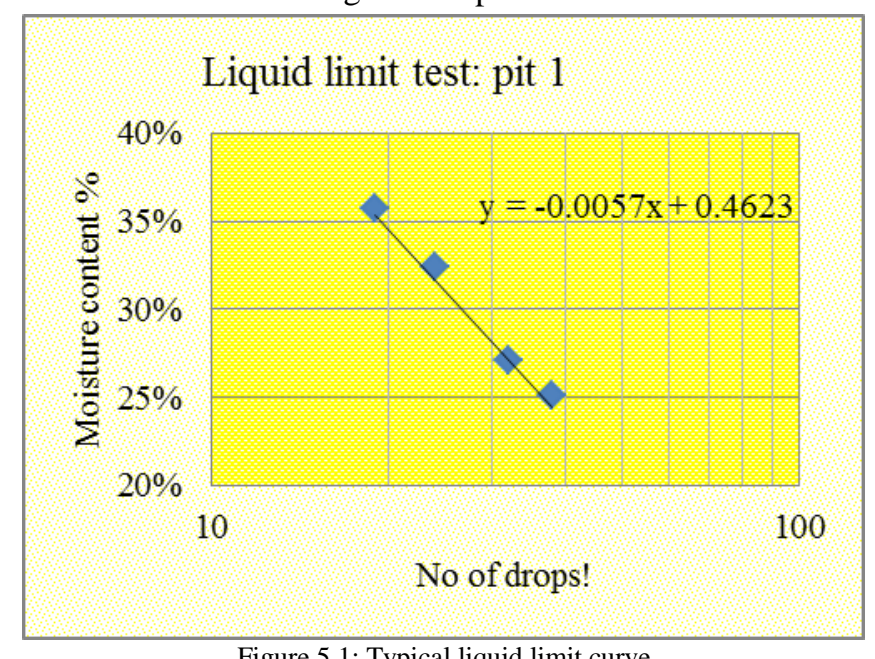

Figure 5.1; Typical liquid limit curve

Table 5.3: Summary Sheet For Atterberg,s Limit Test Results

\begin{tabular}{|c|c|c|c|c|c|c|}
\hline \multirow{2}{*}{ PITS } & \multirow{2}{*}{$\begin{array}{c}\text { Chainage(Sta } \\
\text { tions) }\end{array}$} & \multicolumn{3}{|c|}{ Atterberg,s limit } & \multirow{2}{*}{$\begin{array}{l}\text { Liquidity Index LI=(w- } \\
\text { PL)/LL-PL) }\end{array}$} & \multirow{2}{*}{$\begin{array}{c}\text { Consistency } \\
\text { by LI }\end{array}$} \\
\hline & & LL \% & PL \% & PI $\%$ & & \\
\hline 1 & $9+160$ & 31.98 & 23.91 & 8 & -1.66 & Solid state \\
\hline 2 & $10+200$ & 35.64 & 24.12 & 12 & -1.10 & Solid state \\
\hline 3 & $11+100$ & 23.54 & 20.71 & 3 & -3.48 & Solid state \\
\hline 4 & $12+000$ & 25.58 & - & NP & 0.59 & Solid state \\
\hline 5 & $13+060$ & 49.71 & 35.63 & 14 & -0.88 & Solid state \\
\hline 6 & $14+320$ & 71.95 & 37.1 & 35 & 0.12 & plastic state \\
\hline 7 & $15+380$ & 28.52 & 22.85 & 6 & 0.30 & plastic state \\
\hline 8 & $16+500$ & - & - & NP & - & Solid state \\
\hline 9 & $17+660$ & 46.5 & 36.58 & 10 & -0.47 & Solid state \\
\hline 10 & $19+900$ & 49.87 & 36.66 & 13 & -0.08 & Solid state \\
\hline 11 & $21+000$ & 21.29 & - & NP & - & Solid state \\
\hline 12 & $22+040$ & 35.89 & 30.13 & 6 & -0.29 & Solid state \\
\hline 13 & $23+300$ & 43.17 & 32.97 & 10 & -0.29 & Solid state \\
\hline 14 & $24+220$ & 37.61 & 28.41 & 9 & 0.93 & plastic state \\
\hline 15 & $25+400$ & 46.16 & 33.31 & 13 & 0.80 & plastic state \\
\hline 16 & $26+420$ & 87.31 & 58.77 & 29 & 0.50 & plastic state \\
\hline 17 & $27+200$ & 45.77 & 26.57 & 19 & 0.85 & plastic state \\
\hline
\end{tabular}

(Note: $\mathrm{LI}<0$ is semi-solid or solid state, $\mathrm{LI}=0$ is very stiff state, $\mathrm{LI}=1$ is very soft state, $0<\mathrm{LI}<1$ is plastic state and $\mathrm{LI}>1$ is liquid state.)

Values of liquid limit and plastic limits of pit samples were determined as described in chapter four and their values are given in table 5.3.

As indicated in table 5.3, results obtained from laboratory tests consists both plastic and none plastic soil. Lower plastic index dictates some amount silt content and predominance of sand. None plastic result show supremacy of sand soil since sandy soils change from the liquid state to the semi-solid relatively abruptly. Sandy soils are Cohesion-less and they have no plasticity phase as stated in chapter two.

Liquidity index was calculated for all the samples and tabulated in table 5.3. It indicates the subgrade condition on the site as given in the same table. From this the subgrade soils from pit 14 to 17 are under plastic state. Also PI greater than $20 \%$ is bad for subgrade material for pavement design as ERA site investigation and pavement design manual 2013.

\subsubsection{Soil Classification; (AASTH M145)}

Soils in this research are classified according to AASHTO classification system and are also evaluated by group index whether they are suitable for subgrade for highway construction.

As emphasized; soil classification system depended on classification test conducted for grain size analysis and Atterber's limit test. With having these test results obtained from laboratory; subgrade soils from the study area were classified here below according to AASHTO soil classifications system. 
Soils are grouped under both granular materials $(35 \%$ or less passed on $0.075 \mathrm{~mm}$ sieve) and silty-clay materials (> $35 \%$ passed by $0.075 \mathrm{~mm}$ ) general class. These general classified soil classes are divided in to sub-classification subgroups as A-1 to A-7 and corresponding soil descriptions are also given in Table 5.4.

Table 5.4: AASHTO Soil Classification System

\begin{tabular}{|c|c|c|c|c|c|c|c|c|}
\hline \multirow{3}{*}{ Pits } & \multirow{2}{*}{\multicolumn{3}{|c|}{$\begin{array}{c}\text { Sieve analysis } \\
\% \text { ge of pass }\end{array}$}} & \multirow{2}{*}{\multicolumn{3}{|c|}{ Atterbeg's Limit }} & \multirow{2}{*}{\multicolumn{2}{|c|}{ Soil classification }} \\
\hline & & & & & & & & \\
\hline & $2 \mathrm{~mm}$ & $0.425 \mathrm{~mm}$ & $0.075 \mathrm{~mm}$ & LL \% & PL \% & PI \% & $\begin{array}{c}\text { AASHTO } \\
\text { M145 } \\
\end{array}$ & AASHTO Descriptions \\
\hline 1 & 44.59 & 31.18 & 25.34 & 31.98 & 23.91 & 8 & A-2-4( 0 ) & Silty gravel with Sand \\
\hline 2 & 64.63 & 44.85 & 31.28 & 35.64 & 24.12 & 12 & A-2-6( 0$)$ & $\begin{array}{c}\text { Silty/clay gravel With } \\
\text { Sand }\end{array}$ \\
\hline 3 & 31.69 & 16.72 & 14.36 & 23.54 & 20.71 & 3 & A-2-4 (0) & Silty Gravel With Sand \\
\hline 4 & 54.02 & 35.82 & 17.59 & 25.58 & - & NP & A-3 (0) & Fine Sand \\
\hline 5 & 95.03 & 80.81 & 62.89 & 49.71 & 35.63 & 14 & A-7-5 ( 9$)$ & Clay Soil \\
\hline 6 & 97.35 & 91.83 & 73.23 & 71.95 & 37.1 & 35 & A-7-5 (31) & Highly Plastic Clay \\
\hline 7 & 56.27 & 46.27 & 26.37 & 28.52 & 22.75 & 5 & A-2-4 ( 0$)$ & Low Plastic Silt \\
\hline 8 & 27.45 & 12.15 & 4.66 & - & - & NP & A-1-a ( 0) & Gravel-Sand Mixtures \\
\hline 9 & 81.29 & 64.23 & 46.45 & 46.5 & 36.58 & 10 & A-5 (3) & Low Plastic Silt \\
\hline 10 & 85.97 & 68.19 & 51.96 & 49.87 & 36.66 & 13 & A-7-5 (5) & Highly Plastic Silt \\
\hline 11 & 44.67 & 21.72 & 16.62 & 21.29 & $\mathrm{NP}$ & NP & A-3 (0) & Fine Sand \\
\hline 12 & 97.16 & 82.29 & 63.83 & 35.89 & 30.13 & 6 & A-4 (3) & Low Plastic Silt \\
\hline 13 & 80.13 & 63.11 & 53.09 & 43.17 & 32.97 & 10 & A-5 (4) & Low Plastic Silt \\
\hline 14 & 90.07 & 79.18 & 65.39 & 37.61 & 28.41 & 9 & A-4 (5) & Low Plastic Silt \\
\hline 15 & 93.21 & 74.01 & 54.1 & 46.16 & 33.31 & 13 & A-7-5 (6) & Clay Soil \\
\hline 16 & 97.72 & 91.04 & 76.96 & 87.31 & 58.77 & 29 & A-7-5 ( 30) & Clay Soil \\
\hline 17 & 96.12 & 86.28 & 71.96 & 45.77 & 26.57 & 19 & A-7-5 (14) & Low Plastic Clay \\
\hline
\end{tabular}

Classification is further observed using AASHTO M 145 plasticity chart; which is developed by plotting plastic index (\%) verses liquid limit result (\%) as shown in figure 5.2. this figure is needed for only subgrade soil classes under sub-grouped of A4, A-5, A-6 and A-7; since it considered only silty-clay main soil group. 


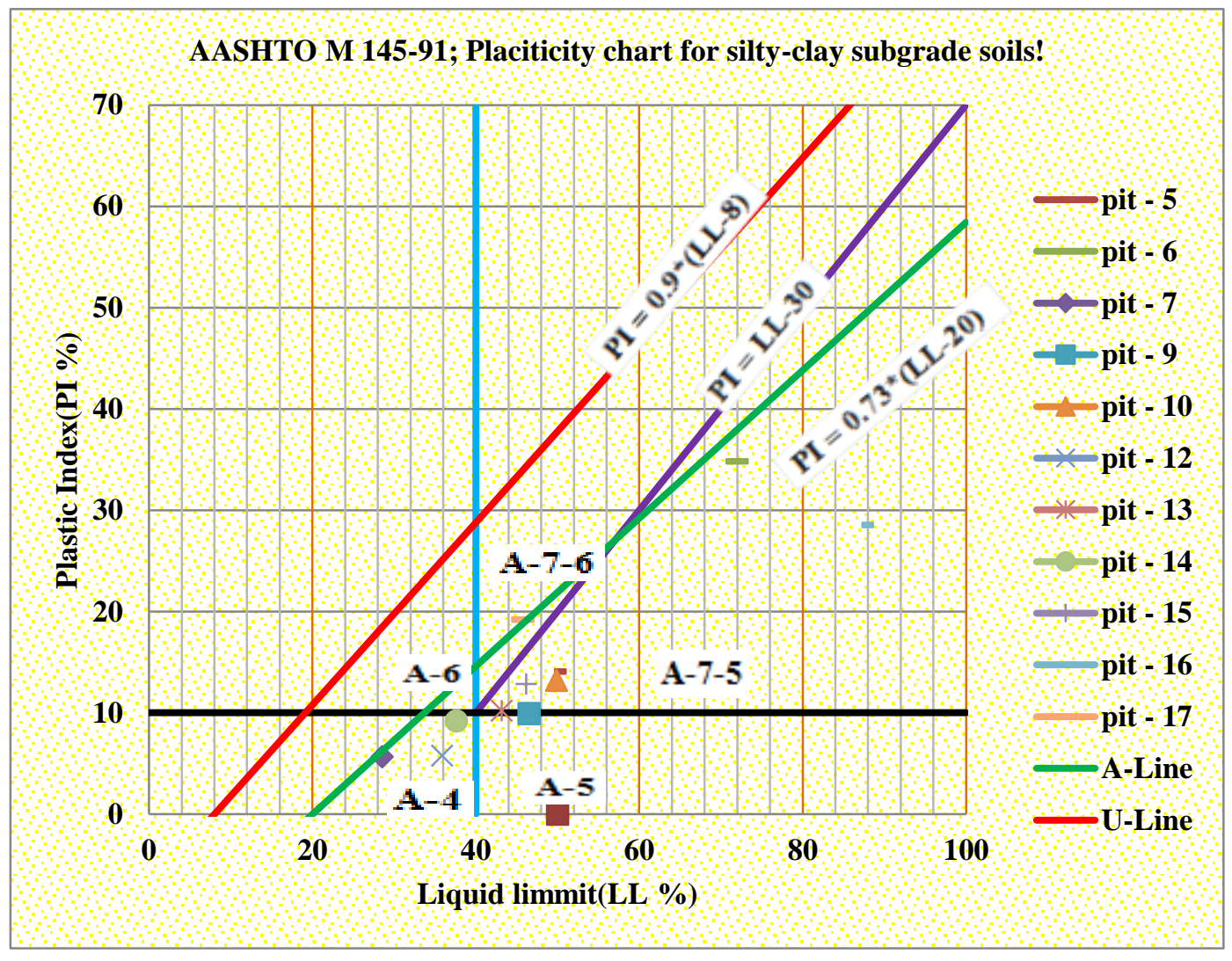

Figure 5.2: AASHTO M 145 plasticity chart of soil classification

As table 5.4 and figure 5.2 presented; subgrade soils along Arbaminch-Chencha existing road are classified in general group of granular materials (A-1,A-2, A-3) and silty-clay materials (A-4, A-5 and A-7) with their corresponding subgroup as A-1-a, A-3, A-2-4, A-2-6, A-3 and A-4, A-5, A-7-5 respectively.

AASHTO soil class grouped under A-1 (Pit-8) was the best whereas grouped under A-7(pits-5, 6, 15, 16 and 17) were the worst for subgrade material for road construction. Off course, problems were observed there in the field also during site survey and sample collection for these pit locations. But, in actual condition of this road it was not as such worst; since the road is under use with proper maintenances provided.

From overall, it is revealed that soils in Arbaminch-Chencha existing road is dominated by fine grained soil classes. This is $59 \%$ fine grained (10 from 17 pits) whereas $41 \%$ is coarse grained soils ( 7 from 17 pits).

5.1.5.1 Evaluating subgrade soil by using group index (GI)

Table 5.5: Evaluating Subgrade Soil According To Group Index

\begin{tabular}{|c|c|c|c|c|c|c|}
\hline \multirow{3}{*}{ PIT No. } & \multirow{3}{*}{$\begin{array}{l}\text { Chainage } \\
\text { (Stations) }\end{array}$} & \multirow{3}{*}{ GI } & \multicolumn{4}{|c|}{ Soil Class } \\
\hline & & & \multicolumn{2}{|c|}{ AASHTO-145 } & \multicolumn{2}{|c|}{ As per ERA( 2013) specification } \\
\hline & & & Group & Rating as a subgrade & subgrade categories & $\begin{array}{c}\text { Suitability as Subgrade } \\
\text { by GI }\end{array}$ \\
\hline 1 & $9+160$ & 0 & A-2-4( 0$)$ & Excellent to Good & Good - Very Good & Good \\
\hline 2 & $10+200$ & 0 & A-2-6( 0$)$ & Excellent to Good & Good - Very Good & Good \\
\hline 3 & $11+100$ & 0 & A-2-4 (0) & Excellent to Good & Good - Very Good & Good \\
\hline 4 & $12+000$ & 0 & A-3 (0) & Excellent to Good & Good - Very Good & Good \\
\hline 6 & $14+320$ & 31 & A-7-5 (31) & pair to poor & Bad - Medium & $\mathrm{Bad}$ \\
\hline 7 & $15+380$ & 0 & A-2-4 ( 0$)$ & Excellent to Good & Good - Very Good & Good \\
\hline 8 & $16+500$ & 0 & A-1-a (0) & Excellent to Good & Good - Very Good & Good \\
\hline 9 & $17+660$ & 3 & A-5 (3) & pair to poor & Bad - Medium & Medium \\
\hline 10 & $19+900$ & 5 & A-7-5 (5) & pair to poor & Bad - Medium & $\mathrm{Bad}$ \\
\hline 11 & $21+000$ & 0 & A-3 (0) & Excellent to Good & Good-Very Good & Good \\
\hline 12 & $22+040$ & 3 & A-4 (3) & pair to poor & Bad - Medium & Medium \\
\hline 13 & $23+300$ & 4 & A-5 (4) & pair to poor & Bad - Medium & Medium \\
\hline 15 & $25+400$ & 6 & A-7-5 (6) & pair to poor & Bad - Medium & $\mathrm{Bad}$ \\
\hline 16 & $26+420$ & 30 & A-7-5 (30) & pair to poor & Bad - Medium & $\mathrm{Bad}$ \\
\hline 17 & $27+200$ & 14 & A-7-5 (14) & pair to poor & Bad - Medium & $\mathrm{Bad}$ \\
\hline
\end{tabular}


Soils are evaluated by their group index properties to indicate the suitability of subgrade for road construction. Group index was calculated as granular soils with zero group indexes and fine soils of different group index values are tabulated in table 5.6. Zero group index results indicate soils of the study area with good quality material be used for sub-grade.

AASHTO and ERA standards separated soils for the suitability for subgrade according to its soil rating criteria. Depending on soil group and group index results determined; soil in Arbaminch-Chencha road $41 \%$ excellent to good and $59 \%$ pair to poor rating as subgrade material as per AASHTO standard whereas $41 \%$ good and $18 \%$ medium and $41 \%$ bad as per ERA suitability of soil as subgrade.

Hence, Subgrade materials classified as A-2-6, A-4, A-5 and A-7-5 will require a layer of subbase material if used as subgrade. Whereas Soils classified as A-1-a, A-2-4, and A-3 can be used satisfactorily as subgrade or subbase material.

\subsubsection{Moisture-density relationship}

Natural subgrade compaction is common and purposeful to have compaction characteristics of it. It is required to densify the existing subgrade materials for overlaying pavement structures. Results of moisture density relationship were also used to in the preparation of CBR test specimens.

From this test, the required parameters are maximum dry density (MDD g/cc) and optimum moisture content (OMC \%) which were determined from different densities achieved by different moisture contents. With having different densities and moisture contents density- moisture curve was plotted as curve plotted for pit-16 as shown in figure 5.3 and MDD and OMC were obtained as follow.

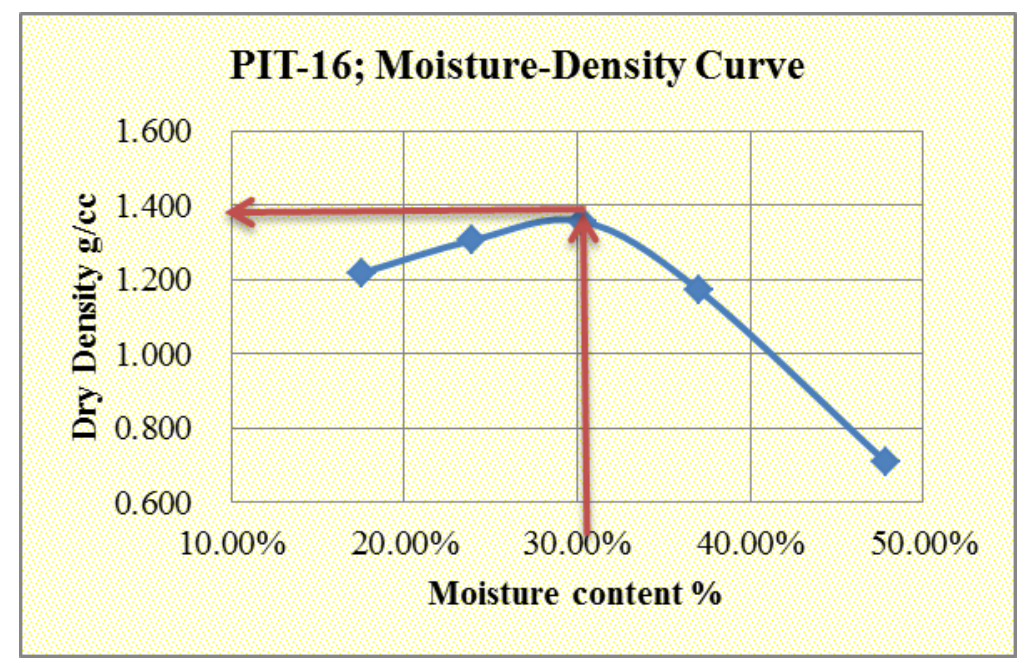

Figure 5.3: Typical Modified proctor compaction test curve

Therefore, by the same way moisture density relationship results were determined and summarized here in table 5.6.

Table 5.6: Summary for Laboratory Moisture- Density Relationship

\begin{tabular}{||c|c|c|c|c|c|}
\hline \multirow{2}{*}{ S.No. } & \multirow{2}{*}{ PITS } & Chain age & \multicolumn{2}{|c|}{ AASHTO T180 } & \multirow{2}{*}{ AASHTO M-145 } \\
\cline { 3 - 5 } & & $\begin{array}{c}\text { (Stations) } \\
\text { OMC\% }\end{array}$ & MDD g/cc & \\
\hline 1 & 1 & $9+160$ & 11.09 & 1.95 & A-2-4( 0) \\
\hline 2 & 2 & $10+200$ & 12.86 & 1.92 & A-2-6( 0) \\
\hline 3 & 3 & $11+100$ & 12.16 & 2.02 & A-2-4 (0) \\
\hline 4 & 5 & $13+060$ & 21.64 & 1.61 & A-7-5 ( 9) \\
\hline 5 & 6 & $14+320$ & 24.44 & 1.58 & A-7-5 (31) \\
\hline 6 & 8 & $16+500$ & 9.47 & 2.11 & A-1-a (0) \\
\hline 7 & 11 & $21+000$ & 23.81 & 1.70 & A-3 $(0)$ \\
\hline 8 & 12 & $22+040$ & 16.82 & 1.90 & A-4 (3) \\
\hline 9 & 14 & $24+220$ & 15.66 & 1.67 & A-4 (5) \\
\hline 10 & 16 & $26+420$ & 30.31 & 1.36 & A-7-5 (30) \\
\hline
\end{tabular}

The results obtained for maximum dry density ranges from 1.36 to $2.11 \mathrm{~g} / \mathrm{cc}$ for optimum moisture content 9.47 to $30.31 \%$. This indicates that the lower values of density are the result of more clay soil with having low bearing capacity whereas the higher values of density are for granular soil materials; which are suitable for subgrade material to withstand traffic loading. The reverse is true for OMC. 


\subsubsection{California Bearing Ratio and Swell}

As per table 4.2, analyzed results of CBR and percentage of swelling under OMC and MDD for ten pit samples are presented here according to given specifications. Since, it is recommended that subgrade $\mathrm{CBR}$ values are required for construction specifications according to AASHTO and ERA design manuals. Hence, subgrade of highways to be compacted in the field at $93 \%, 95 \%$ and $97 \%$ of MDD heavy compaction value obtained in the laboratory to achieve the corresponding CBR values.
To achieve these specifications; CBR observations were already recorded for three different energy level (10, 30 and 65 blows per layer). Analysis of CBR values for above specifications was performed. Here pit-1 was used to show the way of finding CBR results for all specified pit samples in table 5.7 and in figure 5.4 and 5.5.

Table 5.5 describes the CBR values determined at 10 blows per layer only. Nothing is new that; the same way of calculation was done for 30 and 65 blows per layer.

Table 5.7: Typical CBR Analysis under 10 blows/layer

\begin{tabular}{|c|c|c|c|c|c|c|}
\hline \multirow{3}{*}{ pit - 1} & $\begin{array}{l}\text { pen/n piston } \\
\text { area }(\mathrm{mm} 2)\end{array}$ & 1935 & $\begin{array}{l}\text { Penetration Rate } \\
\quad(\mathrm{mm} / \mathrm{Min})\end{array}$ & \multirow{3}{*}{$\begin{array}{l}\text { Standard } \\
\text { Load }\end{array}$} & $\begin{array}{l}2.54 \mathrm{~mm} \\
\text { pen }\end{array}$ & $\begin{array}{c}5.08 \mathrm{~mm} \\
\text { pen }\end{array}$ \\
\hline & $\begin{array}{c}\text { Ring Factor } \\
\text { N/div }\end{array}$ & 21.98 & \multirow[t]{2}{*}{1.27} & & \multirow{2}{*}{$\begin{array}{l}6.9 \mathrm{Mpa} \\
13.2 \mathrm{kN} \\
\end{array}$} & \multirow{2}{*}{$\begin{array}{c}10.3 \\
\mathrm{Mpa} \\
20.0 \mathrm{kN} \\
\end{array}$} \\
\hline & Blows/layer & & & & & \\
\hline $\begin{array}{l}\mathrm{Pen} / \mathrm{n} \\
(\mathrm{mm})\end{array}$ & $\begin{array}{l}\text { Gauge } \\
\text { reading }\end{array}$ & $\begin{array}{c}\text { Load }(\mathrm{N})= \\
\text { Reading*Ring } \\
\text { Factor }\end{array}$ & $\begin{array}{c}\text { Stress N/mm2 = } \\
\text { Load }(\mathrm{N}) / \text { piston Area }\end{array}$ & $\begin{array}{l}* \text { Corrected } \\
\text { Load kN }\end{array}$ & $\begin{array}{l}\text { Standard } \\
\text { Load }(k N)\end{array}$ & CBR \% \\
\hline 0 & 0 & 0.00 & 0.00 & & & \\
\hline 0.64 & 15 & 325.35 & 0.17 & & & \\
\hline 1.27 & 37 & 802.53 & 0.41 & & & \\
\hline 1.91 & 66 & 1431.54 & 0.74 & & & \\
\hline 2.54 & 82 & 1778.58 & 0.92 & 1.85 & 13.20 & 14.02 \\
\hline 3.18 & 91 & 1973.79 & 1.02 & & & \\
\hline 3.81 & 101 & 2190.69 & 1.13 & & & \\
\hline 4.45 & 108 & 2342.52 & 1.21 & & & \\
\hline 5.08 & 115 & 2494.35 & 1.29 & 2.55 & 20.00 & 12.75 \\
\hline 7.62 & 126 & 2732.94 & 1.41 & & & \\
\hline
\end{tabular}

*Corrected load is determined from corrected load-penetration curve.

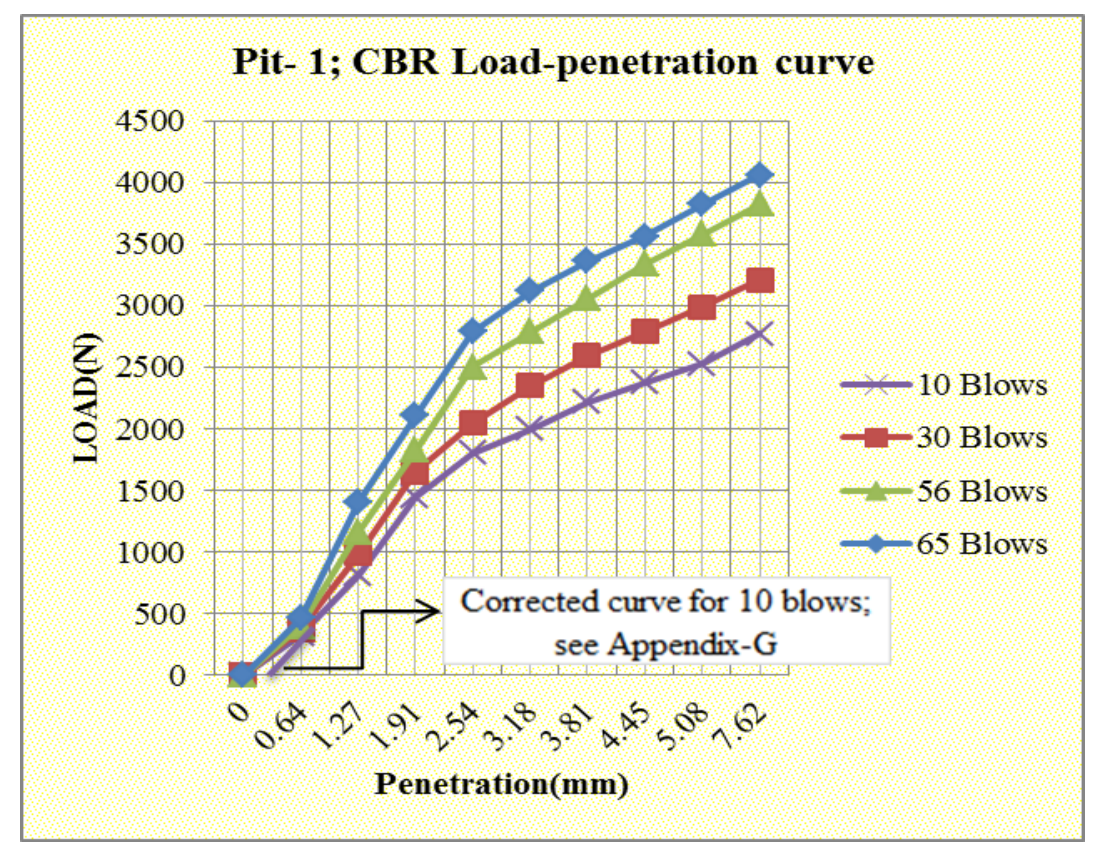

Figure 5.4: CBR Laboratory test Load-penetration curve 
Now, to obtain CBR values at specification of 93\%, 95\% and 97\% MDD; figure 5.5 are plotted (a) for CBR to dry density and (b) for percentage of swelling to dry density. These curves are very important to have desired specification by moving on curves as per AASHTO and ERA standards. CBR and swell values were determined by using equation found in corresponding curves; $\mathrm{y}$-values as CBR or swell values whereas $\mathrm{x}$-values for dry density.

By the similar way overall CBR and swelling results for 10 pit samples were presented in table 5.9 with including corrected load-penetration curves.
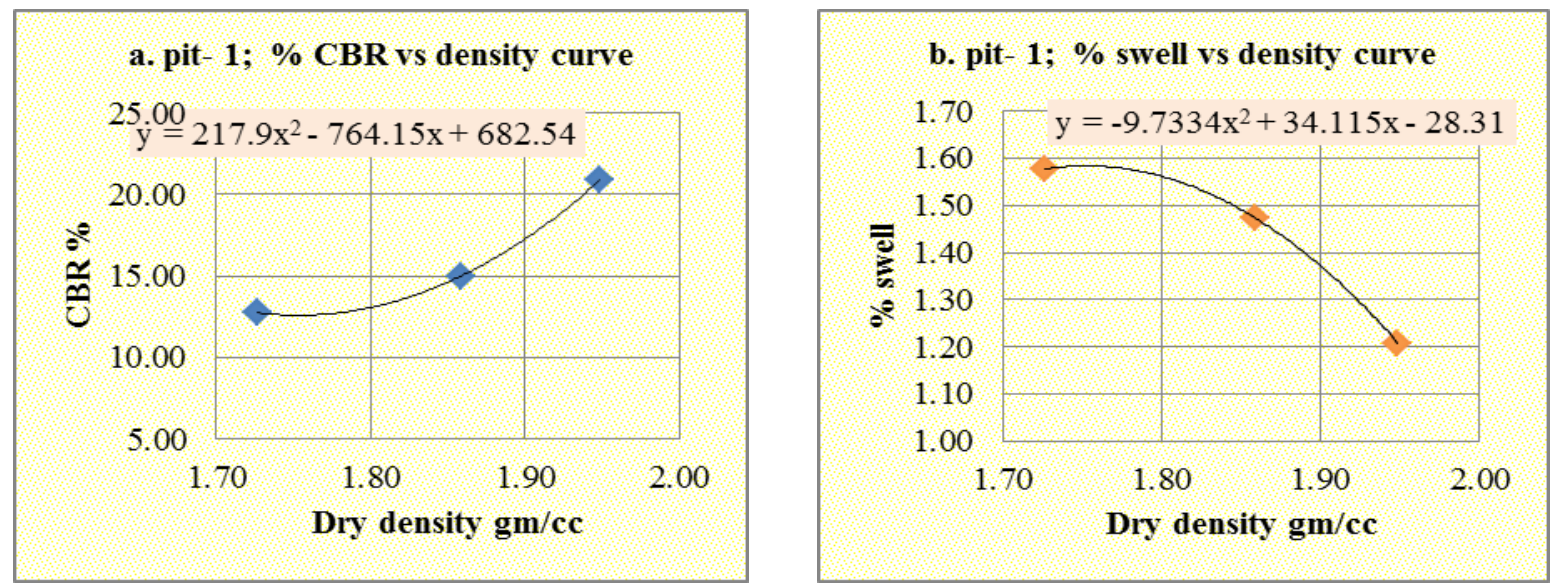

Figure 5.5: CBR and \%ge of Swelling vs Dry density curve for required specification

CBR value for 56 blows per layer was determined here; which was used directly without any analysis in section 5.2 to evaluate the effect of moisture content on CBR. The another purpose of this value here is; to estimate it with respect to other 10,30 and 65 blows per layer in which it lays. As figure 5.4; CBR value for 56 blows per layer is located below 65 and above 10,30 blows per layer.

Table 5.9: CBR specification summary for CBR laboratory test results

\begin{tabular}{|c|c|c|c|c|c|c|}
\hline pit & $\begin{array}{l}\text { Chanaige(stati } \\
\text { on) }\end{array}$ & specification & $\begin{array}{c}93 \% \text { of MDD } \\
\mathrm{g} / \mathrm{cc}\end{array}$ & $\begin{array}{c}95 \% \text { of MDD } \\
\mathrm{g} / \mathrm{cc}\end{array}$ & 56 Blows/layer & $\begin{array}{c}97 \% \text { of MDD } \\
\mathrm{g} / \mathrm{cc}\end{array}$ \\
\hline \multirow{3}{*}{1} & \multirow{3}{*}{$9+160$} & Specified DD g/cc & 1.82 & 1.86 & 1.92 & 1.90 \\
\hline & & CBR at Specified DD (\%) & 13.57 & 15.03 & 18.56 & 17.13 \\
\hline & & Swell at Specified DD (\%) & 1.54 & 1.48 & 1.39 & 1.38 \\
\hline \multirow{3}{*}{2} & \multirow{3}{*}{$10+200$} & Specified DD g/cc & 1.79 & 1.82 & 1.86 & 1.86 \\
\hline & & CBR at Specified DD (\%) & 17.13 & 18.01 & 18.52 & 18.52 \\
\hline & & Swell at Specified DD (\%) & 1.41 & 1.33 & 1.27 & 1.27 \\
\hline \multirow{3}{*}{3} & \multirow{3}{*}{$11+100$} & Specified DD g/cc & 1.88 & 1.92 & 1.96 & 1.96 \\
\hline & & CBR at Specified DD (\%) & 33.82 & 37.16 & 41.58 & 41.58 \\
\hline & & Swell at Specified DD (\%) & 0.46 & 0.42 & 0.37 & 0.37 \\
\hline \multirow{3}{*}{5} & \multirow{3}{*}{$13+060$} & Specified DD g/cc & 1.50 & 1.53 & 1.56 & 1.56 \\
\hline & & CBR at Specified DD (\%) & 4.74 & 5.53 & 6.75 & 6.63 \\
\hline & & Swell at Specified DD (\%) & 2.96 & 2.83 & 2.63 & 2.59 \\
\hline \multirow{3}{*}{6} & \multirow{3}{*}{$14+320$} & Specified DD g/cc & 1.47 & 1.50 & 1.54 & 1.54 \\
\hline & & CBR at Specified DD (\%) & 4.51 & 5.11 & 5.69 & 5.69 \\
\hline & & Swell at Specified DD (\%) & 6.03 & 5.39 & 4.83 & 4.83 \\
\hline \multirow{3}{*}{8} & \multirow{3}{*}{$16+500$} & Specified DD g/cc & 1.97 & 2.01 & 2.05 & 2.05 \\
\hline & & CBR at Specified DD (\%) & 44.35 & 46.70 & 49.72 & 49.22 \\
\hline & & Swell at Specified DD (\%) & 0.33 & 0.31 & 0.31 & 0.30 \\
\hline \multirow{3}{*}{11} & \multirow{3}{*}{$21+000$} & Specified DD g/cc & 1.58 & 1.61 & 1.64 & 1.64 \\
\hline & & CBR at Specified DD (\%) & 11.40 & 12.61 & 13.95 & 13.95 \\
\hline & & Swell at Specified DD (\%) & 0.95 & 0.60 & 0.19 & 0.19 \\
\hline \multirow{3}{*}{12} & \multirow{3}{*}{$22+040$} & Specified DD g/cc & 1.76 & 1.80 & 1.84 & 1.84 \\
\hline & & CBR at Specified DD (\%) & 16.10 & 17.37 & 18.83 & 18.83 \\
\hline & & Swell at Specified DD ( \%) & 1.01 & 0.89 & 0.77 & 0.77 \\
\hline \multirow{3}{*}{14} & \multirow{3}{*}{$24+220$} & Specified DD g/cc & 1.56 & 1.59 & 1.62 & 1.62 \\
\hline & & CBR at Specified DD (\%) & 9.57 & 10.48 & 10.54 & 11.35 \\
\hline & & Swell at Specified DD (\%) & 1.69 & 1.59 & 1.42 & 1.51 \\
\hline \multirow{3}{*}{16} & \multirow{3}{*}{$26+420$} & Specified DD g/cc & 1.26 & 1.29 & 1.32 & 1.32 \\
\hline & & CBR at Specified DD (\%) & 3.39 & 3.86 & 4.40 & 4.40 \\
\hline & & Swell at Specified DD (\%) & 4.18 & 3.84 & 3.49 & 3.49 \\
\hline
\end{tabular}


So that, CBR value of the subgrade on the ArbamincChencha road ranges $3.39 \%$ to $44.35 \%, 3.86 \%$ to $46.70 \%$ and $4.40 \%$ to $49.22 \%$ per specification of $93 \%, 95 \%$ and $97 \%$ MDD respectively. The maximum swell result observed are $6.03 \%, 5.39 \%$ and $4.83 \%$; and $4.18 \%, 3.84 \%$ and $3.49 \%$ for pit 6 and 16 under specification of 93\%, 95\% and 97\% MDD respectively. These shows the CBR values are considerably reduced near Chencha town.

Hence, the soil has high swell value and cannot be used as subgrade soil or requires some kind of treatment and or replacement by good materials Whereas the minimum is
$0.3 \%$ for pit 8 under specification of $97 \%$ MDD which is the very suitable for subgrade. Generally, subgrade soil in present research area was of CBR values various from $3.39 \%$ (unsuitable) to $49.22 \%$ (Suitable) with the average CBR value of $17 \%$ (suitable for highway subgrade construction).

\subsection{Effect of Moisture on CBR Values of subgrade}

5.2.1 Effect of Moisture on CBR Values by varying moisture

This section was observed in section 4.2; for selected three different soil classes. So that soil classes used for the effect of moisture content are tabulated here in table 5.10 with their soil group and CBR already determined in table 5.9.

Table 5.10: Soil Classes used for Effect of Moisture on CBR

\begin{tabular}{||c|c|c|c||}
\hline $\begin{array}{c}\text { Selected soil } \\
\text { Class }\end{array}$ & AASHTO M145 & $\begin{array}{c}\text { \%CBR at OMC; } 56 \\
\text { blows/layer, 4days soaked }\end{array}$ & Descriptions \\
\hline Pit -1 & A-2-4(0) & 18.56 & Silty gravel with sand mixture \\
\hline Pit -14 & A-4(5) & 10.54 & Silty soil \\
\hline Pit -5 & A-7-5(9) & 6.75 & Clay soil \\
\hline
\end{tabular}

For these three soil classes; CBR values were determined for four CBR specimens from each soil classes. These CBR specimens; two from dry side and other two from wet side as described in chapter four.

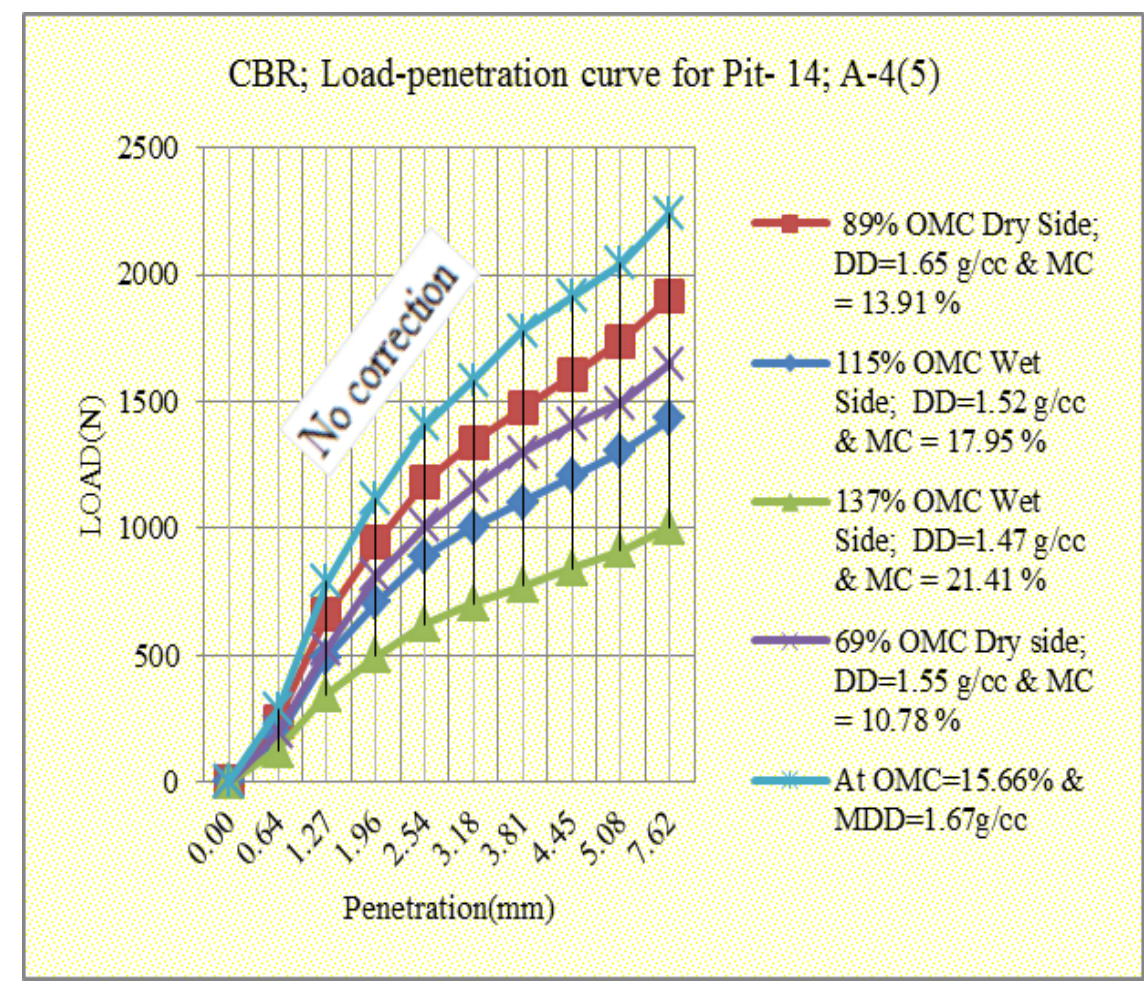

Figure 5.6: Penetration-Load curve for typical soil class

Here is load-penetration curve plotted in figure 5.6 for soil class A-4(5) and results of all three soil classes are summarized in table 5.11 to present the effect of moisture content. Figure 5.6 describes its effect by graphically of CBR values for different moisture contents other than OMC. 
Table 5.11: Summary of Effect of moisture on CBR by drying and wetting

\begin{tabular}{|c|c|c|c|c|c|c|c|c|}
\hline Direction & \multicolumn{2}{|c|}{ Descriptions } & \multicolumn{2}{|c|}{ Pit - 1(A-2-4(0)) } & \multicolumn{2}{|c|}{ Pit $-5(\mathrm{~A}-7-5(30))$} & \multicolumn{2}{|c|}{ Pit - $14(\mathrm{~A}-4(5))$} \\
\hline \multirow{3}{*}{ Dry Side } & \multicolumn{2}{|c|}{ Water amount } & $\begin{array}{l}97 \% \text { OMC } \\
\text { Dry Side; }\end{array}$ & $\begin{array}{l}54 \% \text { OMC } \\
\text { Dry Side }\end{array}$ & $\begin{array}{l}87 \% \text { OMC } \\
\text { Dry Side; }\end{array}$ & $\begin{array}{l}69 \% \text { OMC } \\
\text { Dry Side; }\end{array}$ & $\begin{array}{l}89 \% \text { OMC } \\
\text { Dry Side; }\end{array}$ & $\begin{array}{l}\text { 69\% OMC } \\
\text { Dry side; }\end{array}$ \\
\hline & \multicolumn{2}{|c|}{ Moisture content $\%$} & 8.77 & 5.95 & 18.92 & 14.94 & 13.91 & 10.78 \\
\hline & $\% \mathrm{CBR}$ & 2.54 & 18.11 & 15.64 & 6.09 & 5.24 & 8.89 & 7.57 \\
\hline \multirow{2}{*}{$\begin{array}{l}\text { Effect by } \\
\text { drying }\end{array}$} & \multirow{2}{*}{\multicolumn{2}{|c|}{ wrt OMC \&MDD \%CBR }} & 96.49 & 83.33 & 90.24 & 77.61 & 84.38 & 71.88 \\
\hline & & & 3.51 & 16.67 & 9.76 & 22.39 & 15.62 & 28.12 \\
\hline \multirow{3}{*}{$\begin{array}{c}\text { MDD \& } \\
\text { OMC }\end{array}$} & & \multicolumn{2}{|c|}{11.08} & \multicolumn{2}{|c|}{21.64} & \multicolumn{2}{|c|}{20.08} \\
\hline & \multicolumn{2}{|c|}{ Density $\mathrm{g} / \mathrm{cc}$} & \multicolumn{2}{|c|}{1.95} & \multicolumn{2}{|c|}{1.61} & \multicolumn{2}{|c|}{1.67} \\
\hline & $\begin{array}{c}\% \text { CBR by } 56 \\
\text { blows }\end{array}$ & $2.54 \mathrm{pen} / \mathrm{n}$ & \multicolumn{2}{|c|}{18.56} & \multicolumn{2}{|c|}{6.75} & \multicolumn{2}{|c|}{10.54} \\
\hline \multirow{3}{*}{ Wet Side } & \multicolumn{2}{|c|}{ Water amount } & $\begin{array}{l}\text { 116\% OMC } \\
\text { wet side ; }\end{array}$ & $\begin{array}{c}\text { 145\% OMC } \\
\text { wet side }\end{array}$ & $\begin{array}{l}105 \% \text { OMC } \\
\text { Wet side; }\end{array}$ & $\begin{array}{c}126 \% \\
\text { OMC Wet } \\
\text { side; }\end{array}$ & $\begin{array}{l}115 \% \text { OMC } \\
\text { Wet Side; }\end{array}$ & $\begin{array}{l}\text { 137\% OMC } \\
\text { Wet Side; }\end{array}$ \\
\hline & \multicolumn{2}{|c|}{ Moisture content $\%$} & 12.82 & 16.2 & 22.65 & 27.22 & 17.95 & 21.41 \\
\hline & $\% \mathrm{CBR}$ & 2.54 & 14.16 & 9.71 & 4.77 & 2.76 & 6.67 & 4.67 \\
\hline \multirow{2}{*}{$\begin{array}{l}\text { Effect by } \\
\text { drying }\end{array}$} & \multicolumn{2}{|c|}{ wrt OMC \&MDD \%CBR } & 75.44 & 51.75 & 70.66 & 40.90 & 63.28 & 44.30 \\
\hline & \multicolumn{2}{|c|}{$\%$ CBR Reduced } & 24.56 & 48.25 & 29.34 & 59.10 & 36.72 & 55.70 \\
\hline
\end{tabular}

Table 5.11 presents the effect of moisture content on CBR values of both dry and wet sides of three subgrade soil classes. In which CBR values obtained here were compared with respect to CBR values (at middle three columns in table 5.11; which were directly used from table 5.9 for 56 blows per layer for corresponding soil classes).

The effect was revealed in figure 5.6 and table 5.11, wet side has the highly reduced the CBR values of soils. Even though, approximately the same amount of water added and/or reduced from OMC. To see here; for soil class A-2-4(0): 46\% (100\%-54\%) OMC reduced to have CBR value of $15.64 \%$ and $45 \%$ (145\%-100\%) OMC added to have CBR value of $9.71 \%$ for dry and wet side of OMC respectively. From this; CBR value at wet side was $62 \%$ of dry side. Which means it is $38 \%$ less than dry side CBR value. The same is true for other two soil classes A-7-5(30) and A-4(5) as emphasized in table 5.11 .

To summarize from table 5.12 for three soil classes; table 5.12 created here only for percent CBR reduced due to variation of moisture content for both dry and wet side of $\mathrm{OMC}$ with respect to (wrt) $\mathrm{CBR}$ at $\mathrm{OMC}$.

Table 5.12: Effect of Moisture reduction of CBR from OMC \&MDD

\begin{tabular}{|c|c|c|}
\hline Directions & Pit - 1(A-2-4(0); Silty Gravel with Sand) & $\begin{array}{l}\text { \% CBR Reduced wrt } \\
\text { CBR at OMC }\end{array}$ \\
\hline \multirow{2}{*}{ Dry Side } & $54 \%$ OMC Dry Side; DD $=1.80 \mathrm{~g} / \mathrm{cc} \& \mathrm{MC}=5.95 \%$ & 16.67 \\
\hline & $97 \%$ OMC Dry Side; $\mathrm{DD}=1.87 \mathrm{~g} / \mathrm{cc} \& \mathrm{MC}=8.77 \%$ & 3.51 \\
\hline \multirow{2}{*}{ Wet Side } & $116 \% \mathrm{OMC}$ wet side $; \mathrm{DD}=1.76 \mathrm{~g} / \mathrm{cc} \& \mathrm{MC}=12.82 \%$ & 24.56 \\
\hline & $145 \%$ OMC wet side $; \mathrm{DD}=1.68 \mathrm{~g} / \mathrm{cc} \& \mathrm{MC}=16.12 \%$ & 48.25 \\
\hline \multicolumn{3}{|c|}{ Pit - 5 (A-7-(30)5; Clay Soil) } \\
\hline \multirow{2}{*}{ Dry Side } & $69 \%$ OMC Dry Side; DD $=1.47 \mathrm{~g} / \mathrm{cc} \& \mathrm{MC}=14.94 \%$ & 22.39 \\
\hline & $87 \%$ OMC Dry Side $; \mathrm{DD}=1.55 \mathrm{~g} / \mathrm{cc} \& \mathrm{MC}=18.92 \%$ & 9.76 \\
\hline \multirow{2}{*}{ Wet Side } & 105\% OMC Wet side; $\mathrm{DD}=1.49 \mathrm{~g} / \mathrm{cc} \& \mathrm{MC}=22.65 \%$ & 29.34 \\
\hline & $126 \%$ OMC Wet side; $\mathrm{DD}=1.35 \mathrm{~g} / \mathrm{cc} \& \mathrm{MC}=27.22 \%$ & 59.10 \\
\hline \multicolumn{3}{|c|}{ Pit $-14($ A-4(5); Silty Soil type $)$} \\
\hline \multirow[t]{2}{*}{ Dry Side } & $69 \%$ OMC Dry side; $\mathrm{DD}=1.55 \mathrm{~g} / \mathrm{cc} \& \mathrm{MC}=10.78 \%$ & 28.13 \\
\hline & $89 \%$ OMC Dry Side; $\mathrm{DD}=1.65 \mathrm{~g} / \mathrm{cc} \& \mathrm{MC}=13.91 \%$ & 15.63 \\
\hline \multirow[t]{2}{*}{ Wet Side } & $115 \%$ OMC Wet Side; $\mathrm{DD}=1.52 \mathrm{~g} / \mathrm{cc} \& \mathrm{MC}=17.95 \%$ & 36.72 \\
\hline & $137 \%$ OMC Wet Side; DD $=1.47 \mathrm{~g} / \mathrm{cc} \& \mathrm{MC}=21.41 \%$ & 55.70 \\
\hline
\end{tabular}

As results and effect of moisture content presented, wet side has highly reduced CBR values than dry side and various in degree with in different soil classes. Finer soils have highly reduced than coarser soils.

Generally, at dry side of OMC; CBR reduced by $16.67 \%$ whereas at wet side reduced by $48.25 \%$ for A-2-4 soil class by reduced and added moisture content of $54 \%$ and $145 \%$ of OMC respectively. By the same way $\mathrm{CBR}$ reduced by $22.39 \%$ and $59.1 \%$ of dry and wet side of A-7-5 soil class by reduced and added moisture content of $69 \%$ and $126 \%$ of $\mathrm{OMC}$; and $28.13 \%$ and $55.70 \%$ dry and wet side of OMC for A-4 soil class by added and reduced moisture by $69 \%$ and $137 \%$ of OMC respectively.

When wet side CBR is compared with dry side values; wet side reduced $31.58 \%, 36.71 \%$ and $27.57 \%$ more than dry side for A-2-4(0), A-7-5(30) and A-4(5) soil classes respectively. 


\subsubsection{Effect Moisture on CBR by Varying Saturation Period}

This is the second way in which the effect of moisture content on CBR values by period of saturation. For that results analyzed and summarized from laboratory data as per section 4.2. To discuss the way of analysis and evaluation, CBR values under different degree of saturation period \{unsoaked, for 2 days(48 hours), 4 days(96 hours) and 6 days(144 hours) for soil class A-4(5) were plotted below.

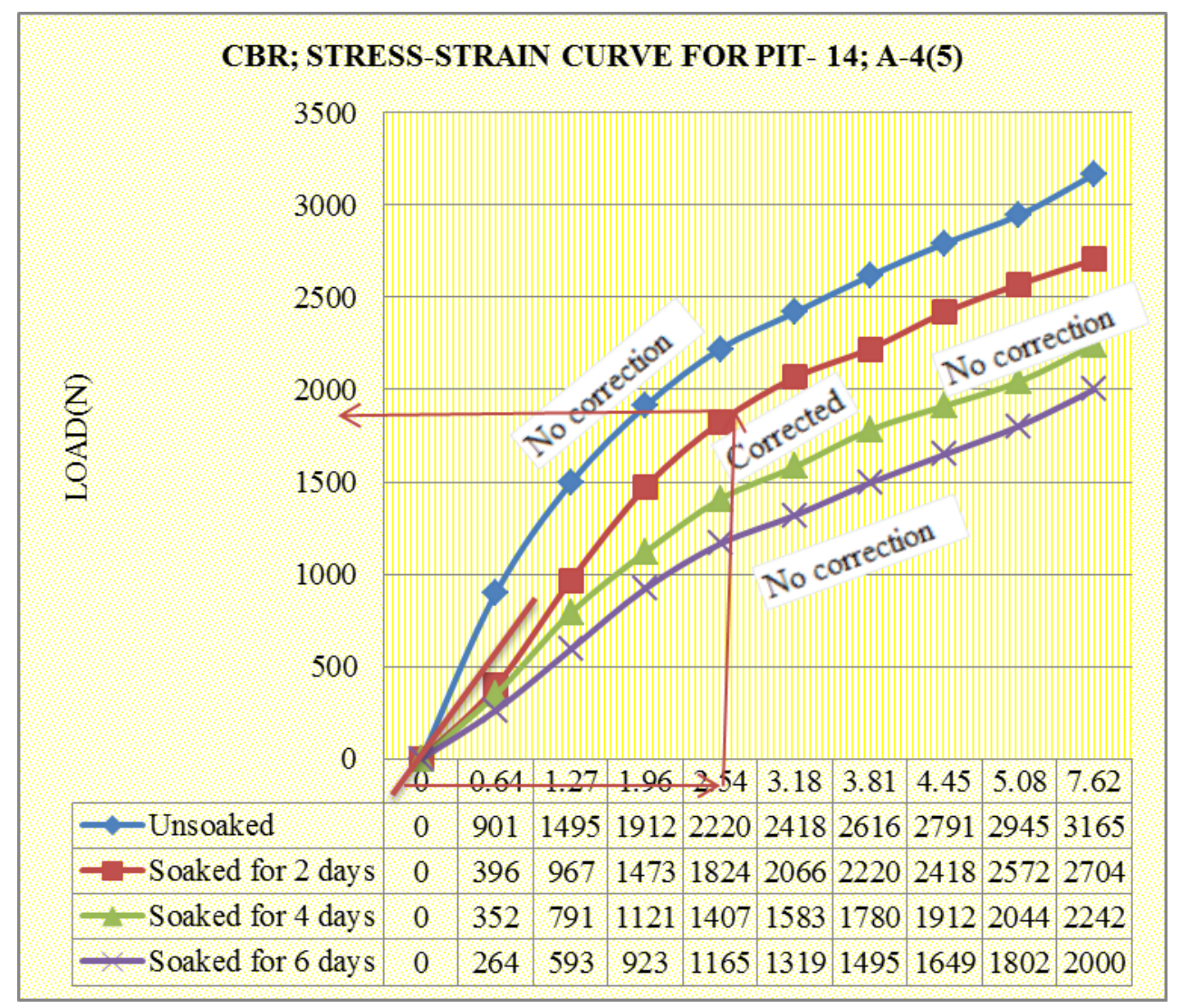

Figure 5.7: Typical Load-penetration curve for effect of saturation on CBR

96 hours soaked CBR results are simply taken from section 5.1.7 at 56 blows per layer; this is why it was included there in section 5.1.7. Hence, it was already determined; no need of test conducted for this saturation period CBR value here again.

The effect of moisture on subgrade CBR values in this section was presented in figure 5.8. The variation of (a) CBR with saturation period and (b) CBR with moisture was observed from chart drawn here in figure 5.8. And combined chart was present in figure 5.9 .
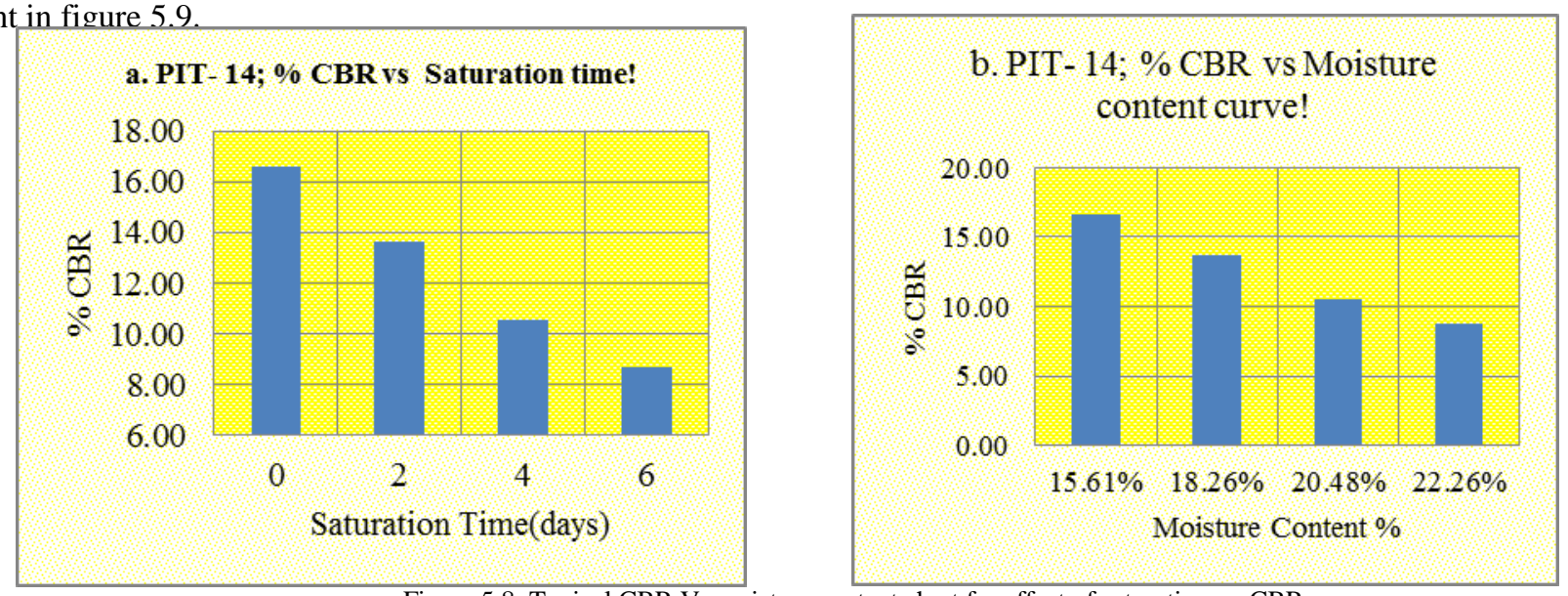

Figure 5.8: Typical CBR Vs moisture content chart for effect of saturation on CBR 
By the same manner the effect was observed for all three soil classes in appendix-I and summarized here in table 5.13.

Table 5.13: Effect of moisture content on CBR by saturation summary

\begin{tabular}{|c|c|c|c|c|c|}
\hline \multirow[b]{2}{*}{ pits } & \multirow{2}{*}{$\begin{array}{c}\text { AASHTO T } \\
180\end{array}$} & \multirow{2}{*}{$\begin{array}{c}\text { Saturation } \\
\text { Period(days) }\end{array}$} & \multirow{2}{*}{$\begin{array}{l}\text { Moisture } \\
\text { content \% }\end{array}$} & \multirow[b]{2}{*}{ \% Swelling } & CBR \\
\hline & & & & & $\begin{array}{c}2.54 \mathrm{~mm} \\
\text { penetration }\end{array}$ \\
\hline \multirow{4}{*}{$\begin{array}{c}1 \text { (A-2-4(0); Silty } \\
\text { gravel sand } \\
\text { mixture })\end{array}$} & MDD g/cc & 0 & 11.31 & 0 & 26.83 \\
\hline & 1.95 & 2 & 14.42 & 1.21 & 21.9 \\
\hline & OMC\% & 4 & 16.05 & 1.39 & 18.77 \\
\hline & 11.8 & 6 & 16.97 & 1.46 & 17.45 \\
\hline \multirow{4}{*}{$\begin{array}{c}5 \text { (A-7-5(9); Clay } \\
\text { Soil) }\end{array}$} & MDD g/cc & 0 & 21.07 & 0 & 10.87 \\
\hline & 1.61 & 2 & 22.78 & 2.2 & 8.4 \\
\hline & $\mathrm{OMC} \%$ & 4 & 25.1 & 2.63 & 6.75 \\
\hline & 21.64 & 6 & 26.79 & 2.84 & 5.43 \\
\hline \multirow{4}{*}{$\begin{array}{c}14(\mathrm{~A}-4(5) ; \text { Silty } \\
\text { soil })\end{array}$} & MDD g/cc & 0 & 15.61 & 0 & 16.63 \\
\hline & 1.67 & 2 & 18.26 & 1.23 & 13.66 \\
\hline & $\mathrm{OMC} \%$ & 4 & 20.48 & 1.42 & 10.54 \\
\hline & 15.66 & 6 & 22.26 & 1.51 & 8.73 \\
\hline
\end{tabular}

As effect observed; reduction of CBR varies with saturation period for all different soil classes. But the reduction is different in different soil class. Thus, for finer soils (A-7$5(30))$ saturation water increases linearly whereas for coarser soils (A-2-4(0)) saturation water increases highly at initial stage up to saturation time 2 days and gradually decreases as emphasized in figure 5.9.

Table 5.14 presents the variation of CBR due to saturation period as discussed above and shows CBR values respect to 4 days soaked CBR (which is taken from table 5.9 for 56 blows).

Table 5.14: Summary sheet of Effect of moisture content on CBR

\begin{tabular}{|c|c|c|c|c|c|c|}
\hline \multirow[b]{2}{*}{ pits } & \multirow{2}{*}{$\begin{array}{c}\text { AASHTO T } \\
180\end{array}$} & \multicolumn{4}{|c|}{ \% CBR } & \multirow{2}{*}{$\begin{array}{c}\text { Effect with respect } \\
\text { to 4day soaked } \\
\text { CBR(\%) }\end{array}$} \\
\hline & & $\begin{array}{c}\text { Saturation } \\
\text { Period(days) }\end{array}$ & $\begin{array}{c}\text { Moisture } \\
\text { content \% }\end{array}$ & $\begin{array}{c}\% \\
\text { Swelling }\end{array}$ & $\begin{array}{c}2.54 \mathrm{~mm} \\
\mathrm{pen} / \mathrm{n}\end{array}$ & \\
\hline \multirow{4}{*}{$\begin{array}{c}\text { 1(A-2- } \\
4(0) ; \text { Silty } \\
\text { grave with } \\
\text { sand mixture) }\end{array}$} & MDD g/cc & $0^{*}$ & 11.31 & 0 & 26.83 & 142.98 \\
\hline & 1.95 & 2 & 14.42 & 1.21 & 21.9 & 116.67 \\
\hline & OMC\% & 4 & 16.05 & 1.39 & 18.56 & 100 \\
\hline & 11.8 & 6 & 16.97 & 1.46 & 17.45 & 92.98 \\
\hline \multirow{4}{*}{$\begin{array}{c}\text { 5(A-7-5(9); } \\
\text { Clay soil) }\end{array}$} & MDD g/cc & 0 & 21.07 & 0 & 10.87 & 160.98 \\
\hline & 1.61 & 2 & 22.78 & 2.2 & 8.4 & 124.39 \\
\hline & OMC\% & 4 & 25.1 & 2.63 & 6.75 & 100 \\
\hline & 21.64 & 6 & 26.79 & 2.84 & 5.43 & 80.49 \\
\hline \multirow{4}{*}{$\begin{array}{l}\text { 14(A-4(5); } \\
\text { Silty Soil) }\end{array}$} & MDD g/cc & 0 & 15.61 & 0 & 16.63 & 157.81 \\
\hline & 1.67 & 2 & 18.26 & 1.23 & 13.66 & 129.69 \\
\hline & $\mathrm{OMC} \%$ & 4 & 20.48 & 1.42 & 10.54 & 100 \\
\hline & 15.66 & 6 & 22.26 & 1.51 & 8.73 & 82.81 \\
\hline
\end{tabular}

*Note: Zero saturation period means CBR test conducted without soaking. 


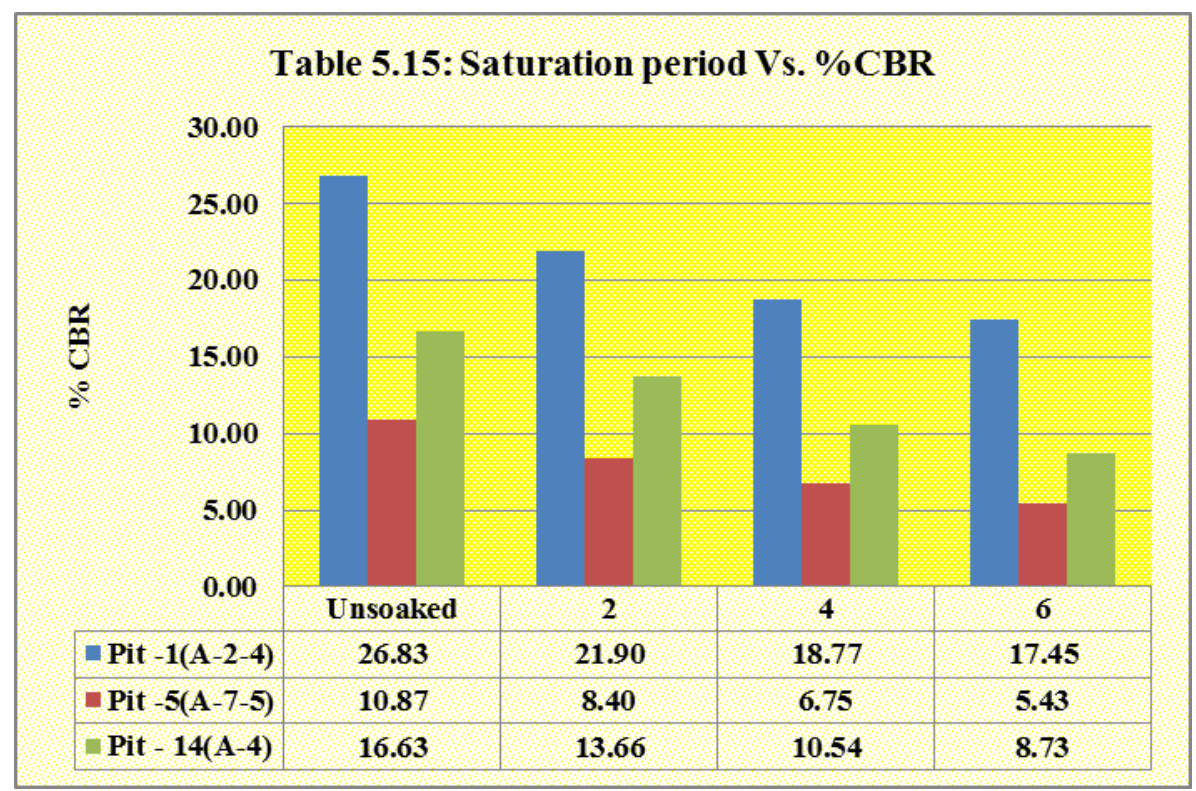

Figure 5.9: Effect of Saturation on CBR; \% CBR vs Saturation period chart

Saturation has continuous adverse effect on subgrade strength (CBR) for both coarse grained and fine grained soil classes. Here, results showed that the reduction of CBR varies with saturation period for different soil classes. For example: A-24 soil class has $82 \%, 70 \%, 65 \%$ for 2,4 and 6 days saturated CBR values with respect to unsoaked CBR value. Whereas A-7-5 soil class has $77 \%, 62 \%$ and $50 \%$ with respect to unsoaked CBR value and $82 \%, 63 \%$ and $53 \%$ with respect to unsoaked CBR for soil class of A-4.
From this, coarser soil classes (A-2-4 and A-4) reduced more just before 48hours saturation and decreases slightly after 96hours whereas finer soil classes (A-7-5) reduced CBR gradually up to 144 hours and continuous somewhat more degree than above soil classes. But, the effect is more in fine grained soils than coarse grained soils. Hence, unsoaked CBR values of soil classes vary from $43 \%$ (coarser soil class) to $61 \%$ (for finer soils) higher than 4 days soaked values.

Here in figure 5.10; the effect of moisture content by saturation period was nicely described for 2 to 4 and 4 to 6 days.

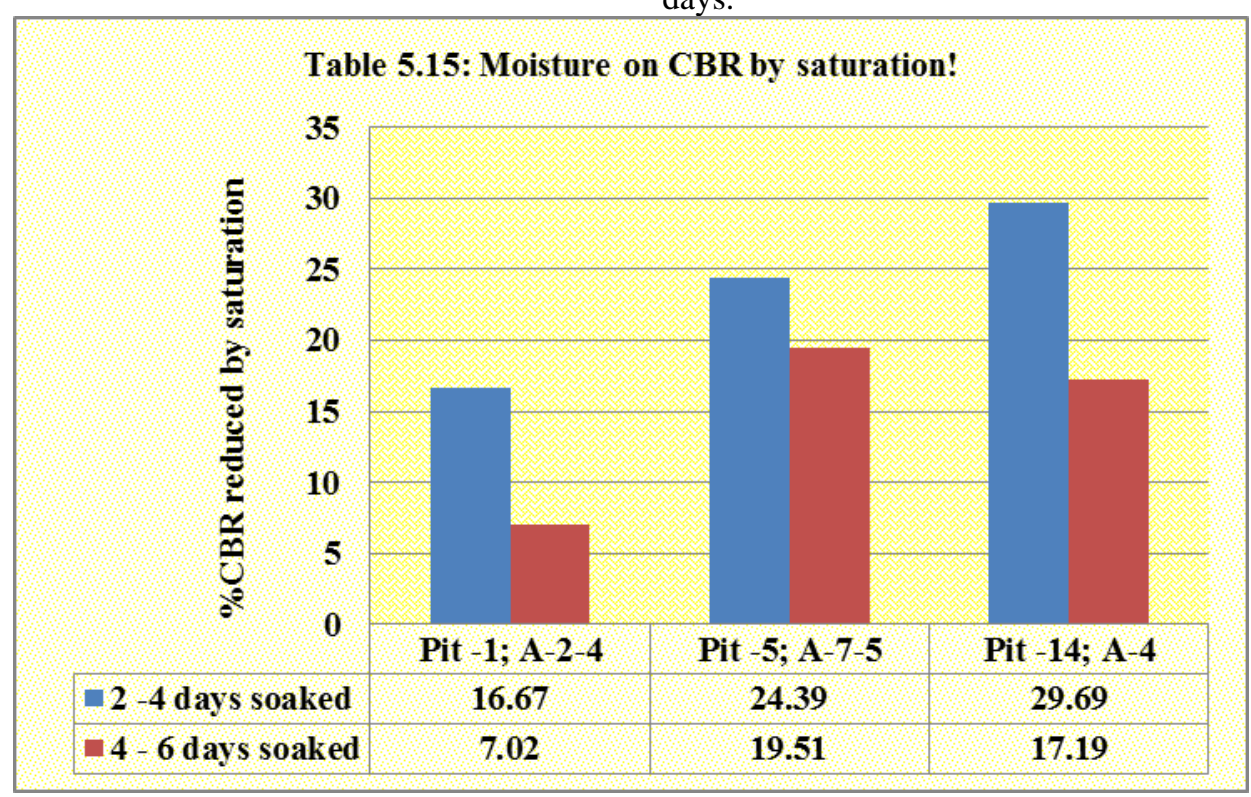

Figure 5.10: Effect of Saturation on CBR; \% CBR vs Saturation period chart

The effect of Saturation after 4th day in coarser soil classes (like Pit 1; A-2-4) was less reduced when compared with the effect on finer subgrade soil classes (Pit 5; A-7-5). So that,
Saturation after 96 hours to 144 hours has reduced CBR of $7.02 \%$ ( Pit - 1; A-2-4) to $19.51 \%$ ( Pit -5; A-7-5) 


\section{CONCLUSION}

IN GENERAL, SUBGRADE SOIL ALONG ARBAMINCH-CHENCHA EXISTING ROAD HAS DIFFERENT SOIL CLASSES, ENGINEERING CHARACTERISTICS AND CBR VALUES; AND ALSO MOISTURE EFFECT. SO THAT, BASED ON THE LABORATORY INVESTIGATION RESULTS ON THIS SUBGRADE SOIL, THE FOLLOWING CONCLUSIONS CAN BE DRAWN:

1) The in-situ moisture content of this subgrade ranges from 10 to $44 \%$ whereas the specific gravity is ranges from 2.62 to 2.75 .

2) Subgrade soil classified by AASHTO M145 classification system as: A-1-a, A-2-4, A-2-5, A-2-6, A-3, A-4, A-5, A-7-5, and which was dominated by fine grained soil class.

3) From Moisture-density relationship, optimum moisture content(OMC\%) ranges from $10 \%$ to $30 \%$ whereas maximum dry density (MDD g/cc) ranges from 1.36 to $2.11 \mathrm{~g} / \mathrm{cc}$. for general concept dry density decreases when the road comes to Chencha from Arbaminch.

4) Some of the pits in the road are good for both subgrade and subbase material for road construction purpose. For example, pit 3 and 8 having PI of 3\% and NP, 95\% MDD CBR value of $37 \%$ and $47 \%$ respectively. Hence, these subgrade materials are good for construction of sub base.

5) Effect of moisture content on CBR was different for different soil classes before and after OMC. As observed, CBR value reduced $4 \%$ to $28 \%$ at dry side whereas $25 \%$ to $59 \%$ at wet side of OMC and MDD of specified soil classes. This indicates that, wet side reduced CBR values $21 \%$ to $31 \%$ more than dry side.

6) Saturation after 48 to 96 hours, CBR reduced from $17 \%$ to $30 \%$ whereas 96 to 144 hours reduced $7 \%$ to $20 \%$. But, more reduction observed in finer soil classes. Therefore, saturation beyond conventional soaking period is significant in the areas in which there is high precipitation; low evaporation and shallow ground water is expected

\section{REFERENCES}

[1] AASHTO T88-2000: Laboratory Particle size analysis of soils

[2] AASHTO M145-2004 Classification of soils and soil aggregates mixtures for highway construction.

[3] ASASHTO T180 and ASTM D1555: Moisture-density relationship of soils and Standard Test Method for Laboratory Compaction Characteristics of Soil Using Modified Effort

[4] AASHTO T193/ ASTM D1883-99: Standard Method of Test for determination of the California Bearing Ratio (CBR) of pavement subgrade, subbase, and base/course materials from laboratory compacted specimens

[5] AASHTO T 265/ASTM D2216-98 - Laboratory determination of moisture content of soils

[6] Abebaw, Z. "Basic Engineering Properties of Lateritic Soils found in Nedjo-Mendi Road Construction Project", Addis Ababa, Ethiopia: M.Sc. thesis, Addis Ababa University, Department of Civil Engineering, AAiT, 2005

[7] Alaba - Sodo - Arbaminch Road Periodic Maintenance Project Engineering Report (ERA final report) 1-2006
[8] Ampadu,S,I.K. (2006), "Laboratory Investigation into the Effect of Water Content on the CBR of a Subgrade soil".

[9] Arora, K.R., "Soil Mechanics and Foundation Engineering", Six Edition, Delhi, India, 2004

[10] ASTM D420: Standard Guide to Site Characterization for Engineering Design and Construction Purposes

[11] ASTM D421(2007) and ASTM D 2217-85(98), Standard Practice for Dry and wet Preparation of Soil Samples for Particle-Size Analysis of soils respectively

[12] ASTM D854/AASHTO T100 (Method-A): Standard Test Method of Laboratory determination for Specific Gravity of Soils

[13] ASTM D2488: Standard Practice for Description and Identification of Soils (Visual-Manual Procedure)

[14] ASTM D 4318 (2004)/ AASHTO T89/90: Standard Test Methods for Liquid Limit, Plastic Limit and Plasticity Index of Soils

[15] Atkinson, J. (2007). The mechanics of soils and foundations/John Atkinson by . (2nd ed.). Park Square, Milton Park, Abingdon, Oxon OX14, USA and Canada: Taylor \& Francis.

[16] Bowles, J.E., "Foundation Analysis and Design", Fifth Edition, the McGraw- Hill Companies Inc., 1996.

[17] Braja. M, D. (2008). Soil Mechanics Laboratory Manual (Sixth ed.). New York Oxford ( Oxford University,Press): Sacramento

[18] C.Venkatramaiah. (2006). Geotechnical engineering (revised third ed.). Tirupati, India: new age international publishe.

[19] ERA Site Investigation manual 2013 and ERA flexible pavement design Manual, volume 1 -2013; www.era.gov.et

[20] IRC-SP 37-2007, Guide line for the design of flexible pavement materials for highway construction

[21] Nibret Chane 2011; Geotechnical Characterization of Sub grade Materials for Pavement Construction on Aposto - Wondo - Negele Road Upgrading Project

[22] Nugroho,S.A., Hendri,A., Ningsih,S.R.(2012), Correlation between index properties and california bearing ratio test of pekanbaru soils with and without soaked.Canadian Journal on Environmental, Construction and Civil Engineering Vol. 3,Indonesia

[23] Pragyanshree Padhy (May 2013) "A Study on Effects of Saturation on Soil Subgrade Strength research".

[24] Razouki,S.S., Al-Azawi,M.S.(2003),"long - term soaking effect on strength and deformation characteristics of a gypsiferous subgrade soil'.Engineering Journal of the University of Qatar, Vol. 16,Iraq pp49-60.

[25] Singh,et al(2011), Moisture and Compaction Based Statistical Model for Estimating CBR of Fine Grained Subgrade Soils.International Journal of Earth Sciences and Engineering

[26] Tanzania field and laboratory soil testing manual; central materia laboratory, Dar es salaam June 2000.

[27] Terzaghi, K. and Peck, R. B., "Soil Mechanics in Engineering Practice" July 2007.

[28] Transport Research Laboratory (TRL) Ltd (1999); Guidelines on the Selection and Use of Construction Materials. Department for International Development (DFID), Report No. R/INT/203/00 R6898. London, UK

[29] Wesley, L. D. Geotechnical engineering in residual soils. Hoboken, New Jersey: John Wiley \& Sons, Inc., 2010 